\title{
19. UPPER NEOGENE AND QUATERNARY PLANKTONIC FORAMINIFERS FROM THE BLAKE OUTER RIDGE AND BLAKE-BAHAMA BASIN (WESTERN NORTH ATLANTIC), DEEP SEA DRILLING PROJECT LEG 76, SITES 533 AND 5341
}

\author{
Michel Moullade, Centre de Recherches Micropaléontologiques “Jean Cuvillier”, Université de Nice, Parc Valrose,
} 06034 Nice Cedex, France

\begin{abstract}
Four holes were drilled at two sites in the western North Atlantic during Deep Sea Drilling Project Leg 76 . Thick Pliocene-Quaternary sediments were continuously cored in Holes 533 and 533A, located on the Blake Outer Ridge. A detailed biostratigraphic study of the upper Neogene and Quaternary strata has been made using distribution of planktonic foraminifers. Precision of the biostratigraphic analysis enabled us to trace fluctuations of the sedimentation rate closely. Very high mid-Pliocene input strongly contrasts with the extreme condensation that was noted to have occurred during the latest Pliocene. Quantitative micropaleontology methods have been applied to selected planktonic species or groups of foraminifers, enabling us to discern clearly the oceanic response to large-scale climatic changes, such as the mid-Pliocene glacial event and the Quaternary cycles. In contrast, the small-scale climatic events appeared to be obscured by minor sedimentary disturbances, which could be related to bottom contour-following currents.
\end{abstract}

\section{INTRODUCTION}

During DSDP Leg 76 , four holes that penetrated Neogene through Quaternary sediments were drilled at two sites in the western North Atlantic. Site 533 is located at $31^{\circ} 15.6^{\prime} \mathrm{N}, 74^{\circ} 52.2^{\prime} \mathrm{W}$, at a water depth of 3191 $\mathrm{m}$, on the crest of the Blake Outer Ridge, slightly to the north of Sites 102, 103, and 104 of DSDP Leg 11 (Fig. 1). Hole 533 penetrated $167.6 \mathrm{~m}$ of Quaternary and uppermost Pliocene beds, in which 41 hydraulic piston cores were continuously recovered. At the same location, $399 \mathrm{~m}$ of Quaternary and upper middle Pliocene sediments were drilled in Hole 533A; 29 rotary cores were taken, one upper Pleistocene wash core at a sub-bottom depth of $57 \mathrm{~m}$ and 28 lowermost Pleistocene and upper middle Pliocene cores from a continuously cored interval from 142.5 to $399 \mathrm{~m}$.

Site 534 is located in the Blake-Bahama Basin at $28^{\circ}$ $20.6^{\prime} \mathrm{N}, 75^{\circ} 22.9^{\prime} \mathrm{W}$ (Fig. 1), at a water depth varying from 4984 (Hole 534) to $4976 \mathrm{~m}$ (Hole 534A). Only one uppermost Quaternary mud-line core was recovered from Hole 534. Hole 534A penetrated Quaternary and upper Neogene parts of the Tertiary sequence without any coring down to Miocene strata.

At Site 533, sediments are predominantly composed of greenish calcareous clay and interbedded nannofossil marl and silty clay, whereas Pliocene material is composed of indurated dark greenish gray silty nannofossil clay. No obvious stratification but only some evidences of bioturbation and limestone lithification (the latter restricted to the Pliocene) have been sporadically observed in this series. The uppermost Quaternary mud-line core drilled at Site 534 is composed of $1.75 \mathrm{~m}$ of foraminifernannofossil ooze underlain by $0.35 \mathrm{~m}$ of nannofossil marl.

\footnotetext{
${ }^{1}$ Sheridan, R. E, Gradstein, F. M., et al., Init. Repts. DSDP, 76: Washington (U.S. Govt. Printing Office).
}

Generally abundant and well-preserved populations of planktonic foraminifers, together with minor benthic assemblages, have been extracted for biostratigraphic investigations from about 75 (chiefly core catcher) samples collected from the 71 cores of Holes 533, 533A, and 534. Thirty additional samples selected from three separate test intervals have been considered in more detail for paleoclimatic and paleoceanographic interpretations.

\section{METHODS}

Preparation techniques included boiling of each of the about $10-\mathrm{cm}^{3}$ samples with a Calgon solution, sometimes accompanied by hydrogen peroxide sprinkling, and wet-sieving with a minimum mesh size of $63 \mu \mathrm{m}$. The $\geq 177-\mu \mathrm{m}$ or, in some cases, $\geq 200-\mu \mathrm{m}$ size fraction was only considered for the biostratigraphic study, and the relative abundance of each identified planktonic foraminiferal species was estimated by visual examination. Samples investigated in the three test intervals were dried, weighed before and after washing, and the $\geq 160$ $\mu \mathrm{m}$ size fraction was used for quantitative analysis after microsplitting of the residue and counting of at least 350 to 400 specimens in each sample.

\section{BIOSTRATIGRAPHY}

\section{Planktonic Zonation}

Distribution and estimated relative abundance of Pliocene-Quaternary planktonic foraminifers at Sites 533 and 534 are detailed in Figures 2 to 4 . Common and longranging forms, mostly belonging to the genus Globigerina, have been omitted. Combining results obtained in Holes 533 and 533A, Figure 5 shows more schematically the stratigraphic range of the most important species at Site 533. For establishing the zonal scheme, I have principally applied late Cenozoic zonations of Blow (1969), Parker (1973, 1974), Stainforth et al. (1974), Berggren (1973, 1977), and Berggren and Van Couvering (1974), which are essentially based on data collected in low-latitude areas and chiefly the Atlantic tropical realm. In addition, the climatic zonation of Ericson (Ericson and 


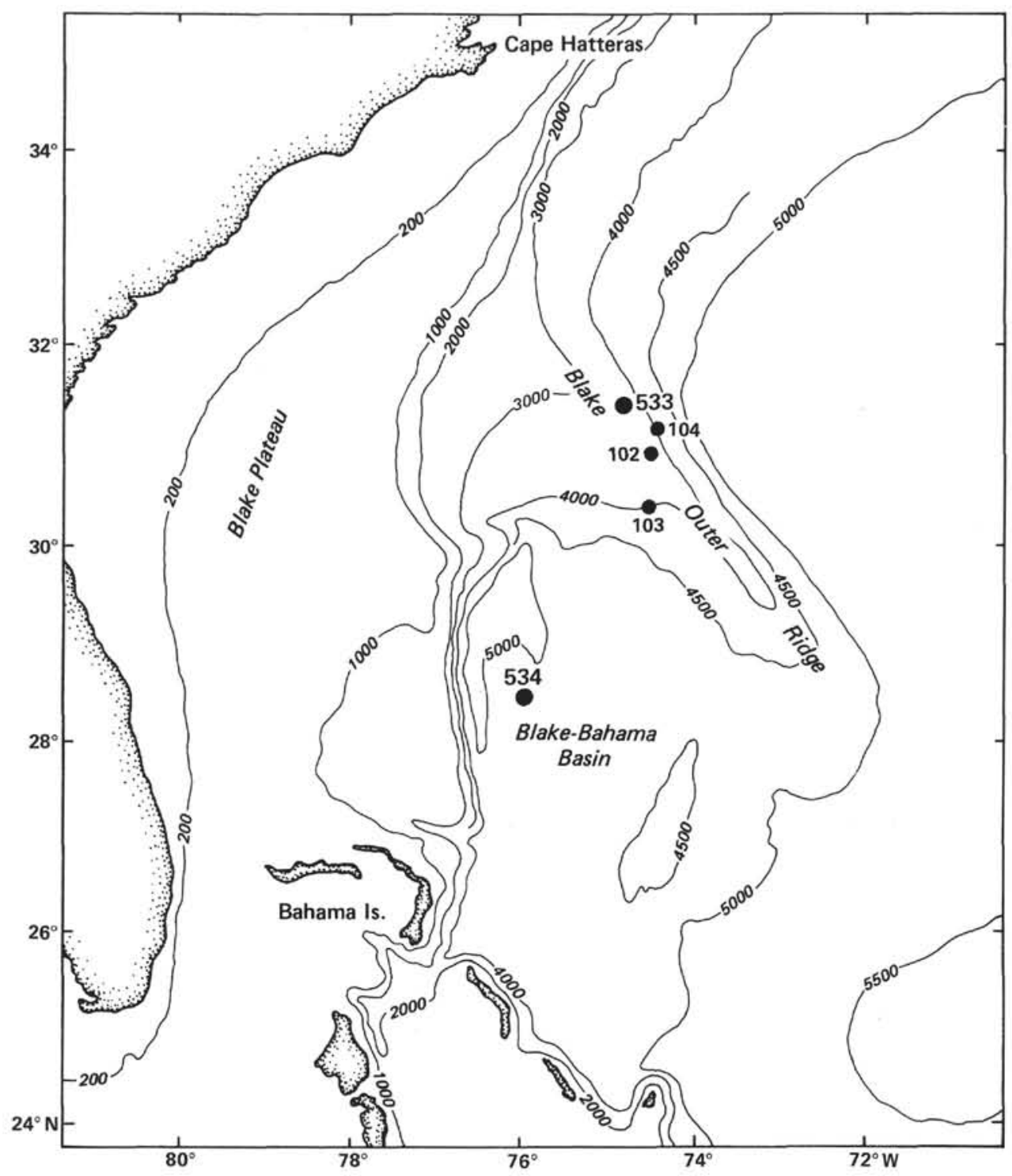

Figure 1. Sketch map showing locations of Sites 533 and 534 relative to previous DSDP sites drilled on the Blake Outer Ridge.

Wollin, 1968) has also been used for the Quaternary sediments of Site 533 .

Datum levels of first and last appearances of the principal markers that were observed in the upper Neogene DSDP Leg 76 material are in general agreement with those noted in similar latitudes by previous workers (e.g., Poag, 1972; Parker, 1973). But there are a few exceptions, which may result from subjective variations in delineation of taxa and/or locally different paleoclimatic and paleoceanographic conditions.

In order to calibrate these important foraminiferal datum levels chronologically at Site 533, values collected or compiled in recent works have been compared; those retained for this study are summarized in Table 1 .

\section{Zonal Boundaries}

\section{Pliocene}

Following the Pliocene zonation of Berggren (1973, 1977), we set the boundary between Zones PL4 and PL5 in Core 533A-7, above Sample 533A-7, CC, based on the last occurrence of Globoquadrina gr. altispira. According to Berggren (1977), Globorotalia multicamerata also disappears at this level. Although very sporadically represented in Site 533 material, this species last occurs in Sample 533A-6,CC, thus furnishing an additional confirmation of the zonal boundary.

More problems arise when trying to delineate the PL3/PL4 (= N20/N21) zonal boundary and minimal age of the beds that are at the bottom of Hole 533A. The lower limit of Zone PL4 may be determined by the FAD of Sphaeroidinella dehiscens dehiscens $(=3.0 \mathrm{Ma})$, which should coincide with the Sphaeroidinellopsis spp. LAD (Berggren, 1977). In Hole 533A, Sphaeroidinella dehiscens s.s. first appears in Sample 533A-8,CC, whereas the last specimens hardly typical of the genus Sphaeroidinellopsis disappear above Sample 533A$11, \mathrm{CC}$. Representatives of this genus are scattered in the interval comprising Cores 11 to 19 , and only from Sample 533A-19,CC did we notice a sharp downhole in- 


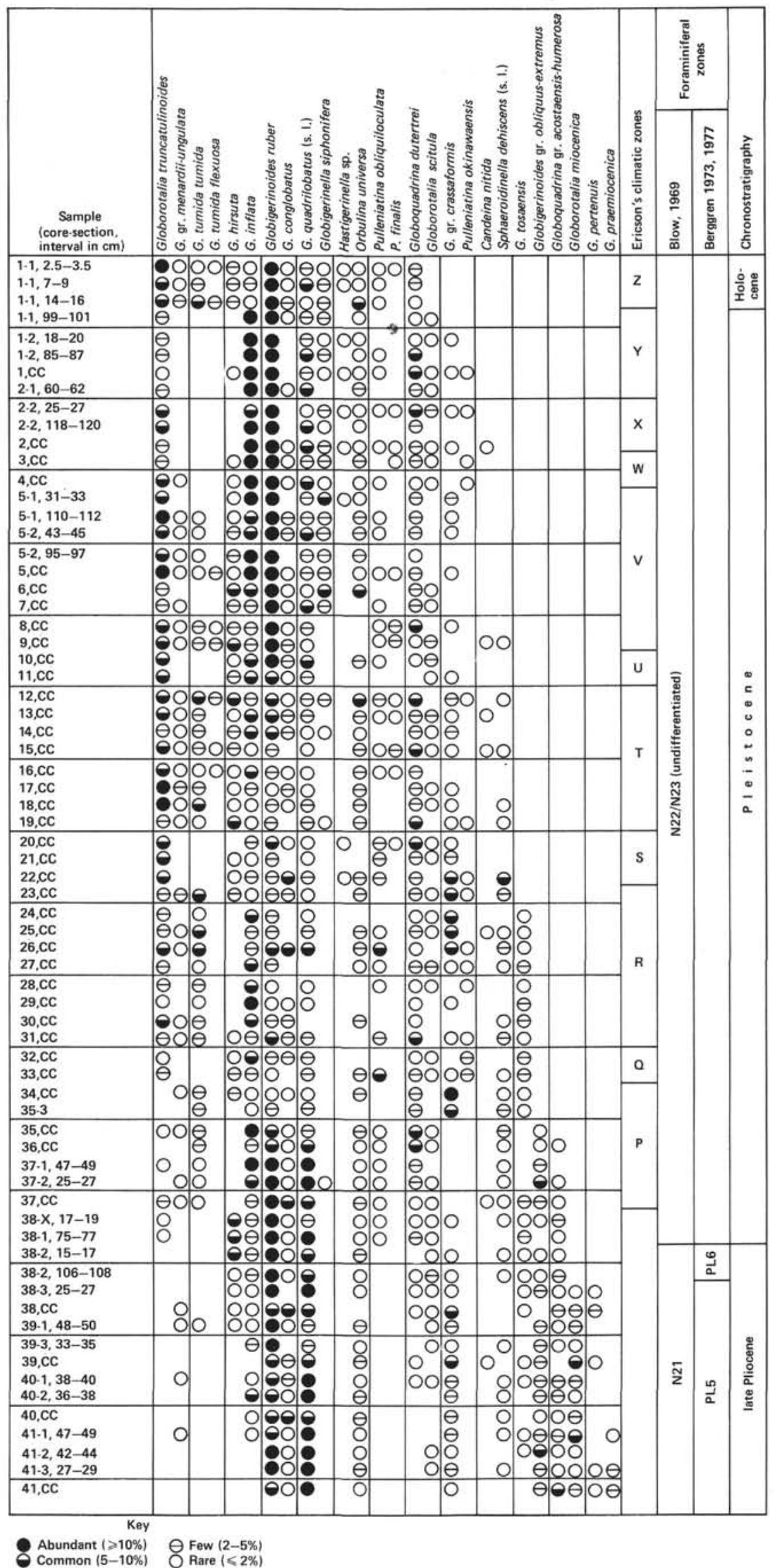

Figure 2. Occurrence of selected planktonic foraminifers in samples from Hole 533. 


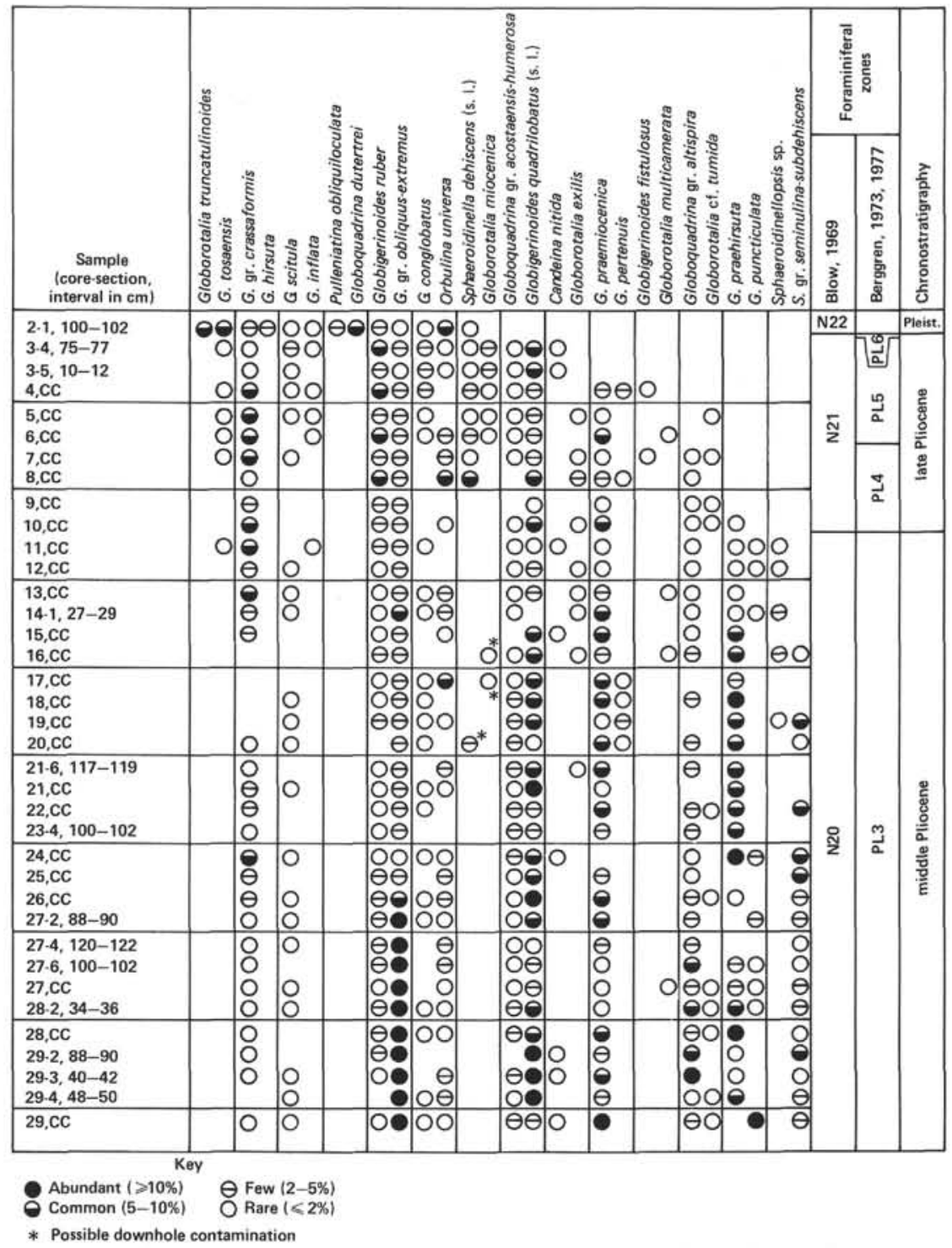

Figure 3. Occurrence of selected planktonic foraminifers in samples from Hole 533A.

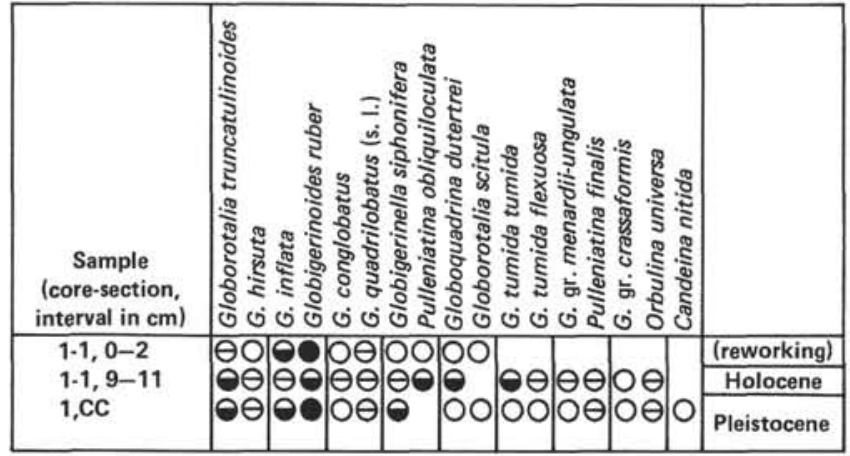

Figure 4. Occurrence of selected planktonic foraminifers in samples from Hole 534 (for explanation of symbols, see Figs. 2 and 3).

crease in abundance of specimens belonging to the $S$. seminulina-subdehiscens complex. There is thus a rather thick interval between the two datums whose coincidenze, according to Berggren (1977) is supposed to de- fine the PL3/PL4 boundary. On the other hand, Roth (this volume) observed the Reticulofenestra pseudoumbilica nannofossil datum (which defines the boundary between NN15 and NN16) between Cores 11 and 12 . The LAD of $R$. pseudoumbilica is calibrated from 2.8 to 3.2 m.y., according to various authors (Backman, 1979; Vincent, 1981), but set at $3.0 \mathrm{~m} . \mathrm{y}$. by Roth (this volume). I have thus tentatively placed the PL3/PL4 zonal boundary (3.0 m.y.) at this level, more exactly, just above Sample 533-11,CC, which also constitutes the uppermost level where (poor) representatives of the genus Sphaeroidinellopsis can be depicted.

Determination of the minimal age of the deepest part of Hole 533A (sub-bottom depth $399 \mathrm{~m}$ ) by means of planktonic foraminifers is still more problematical. Contrary to the results of the preliminary shipboard investigations, Globorotalia margaritae is not present at this level nor higher in the hole. Four-chambered specimens that had been erroneously referred to this species are, in fact, representatives of $G$. praehirsuta. Therefore, the 
Table 1. Biochronology of the main Pliocene-Quaternary planktonic foraminiferal datum levels.

\begin{tabular}{|c|c|c|}
\hline Species & Datum event & Age (m.y.) \\
\hline Globorotalia tumida flexuosa & LAD & 0.1 \\
\hline Sphaeroidinella dehiscens s.1. & $\begin{array}{l}\text { Sharp decrease } \\
\text { in abundance }\end{array}$ & 0.9 \\
\hline Globigerinoides ruber (pink var.) & FAD & 1.1 \\
\hline Pulleniatina finalis & FAD & 1.3 \\
\hline Globigerinoides fistulosus & LAD & 1.6 \\
\hline G. obliquus obliquus & LAD & 1.7 \\
\hline G. obliquus extremus & LAD & 1.8 \\
\hline Globorotalia truncatulinoides & FAD & 1.85 \\
\hline G. miocenica & LAD & 2.2 \\
\hline Globoquadrina gr. altispira & LAD & 2.8 \\
\hline Globigerinoides fistulosus & FAD & 3.0 \\
\hline $\begin{array}{l}\text { Sphaeroidinella dehiscens } \\
\text { dehiscens }\end{array}$ & FAD & 3.0 \\
\hline Sphaeroidinellopsis spp. & LAD & 3.0 \\
\hline Globorotalia margaritae & LAD & 3.3 \\
\hline
\end{tabular}

Note: Data are synthesized from various authors, mainly Rögl and Bolli (1973), Berggren (1977), Berggren et al. (1980), Briskin and Berggren (1975), Backman (1979), Lynts (1980), Bolli and Premoli-Silva (1973), Thunnell (1981), and Vincent (1981). FAD = first appearance datum; LAD = last appearance datum.

bottom of the last core (29) of this hole still belongs to Zone PL3 (the lower boundary of which is defined by the LAD of $G$. margaritae), with an age not older than $3.3 \mathrm{~m} . \mathrm{y}$.

The PL5/PL6 boundary is given by the LAD of $G$. miocenica $(2.2 \mathrm{~m} . \mathrm{y}$.). This datum can be identified with good precision in Core 38 of Hole 533, just at the level of Sample 533-38-3, 25-27 cm (sub-bottom depth, $152.5 \mathrm{~m}$ ).

\section{Pliocene/Quaternary Boundary}

The Pliocene/Quaternary boundary had been determined aboard the ship, based on first investigations using nannofossils, between Sections 1 and 2 of Core 53338. As far as planktonic foraminifers are concerned, further study of a more closely spaced sampling locates this boundary in an interval ranging from Sample 533$38-2,106-108 \mathrm{~cm}$, where Globorotalia tosaensis is represented alone; Sample 533-38-2, 15-17 cm, where one specimen of $G$. tosaensis evolving to $G$. truncatulinoides has been observed; and up to Sample 533-38-1, 75-77 $\mathrm{cm}$, where several specimens of $G$. truncatulinoides have been found. Thus using the FAD of $G$. truncatulinoides as an indication of the Pliocene/Quaternary boundary, I also set this boundary (1.85 m.y.) between Sections 1 and 2 of Core 38 .

This event cannot be delineated with the same precision in Hole 533A, for lack of a sufficiently dense sampling. In addition, some minor problems of contamination may have occurred in Wash Core 2. A massive appearance of G. truncatulinoides in Sample 533A-2-1, $100-102 \mathrm{~cm}$, and detailed comparison between planktonic and benthic foraminiferal assemblages respectively found in Cores 36 to 39 of Hole 533 and Cores 2 to 3 of Hole 533A, allows me to place, with a slight approximation, the Pliocene/Quaternary boundary in the upper third of Core 533A-3. This core is thus approximately equivalent to Cores 38 and 39 of Hole 533 .
All these data confirm the significant and progressive downhole acceleration of the sedimentation rate, which in Site 533 reaches $62.5 \mathrm{~m} / \mathrm{m}$.y. for the interval corresponding to Zone PL5, goes up to $190 \mathrm{~m} / \mathrm{m}$.y. for the PL4 interval, and equals or is higher than $570 \mathrm{~m} / \mathrm{m}$.y. for the interval referred to as Zone PL3.

Retaining the 1.85 -m.y. value for the FAD of $G$. truncatulinoides in the Atlantic mid-latitude zone (Haq et al., 1977; Backman, 1979), it appears that the $175 \mathrm{~cm}$ of sediments ( = PL6 Zone) that separate Sample 533$38-3,25-27 \mathrm{~cm}$ (level of the LAD of G. miocenica, 2.2 m.y.) from the boundary between Sections 1 and 2 of Core 38 should correspond to a 0.35 -m.y. time span. Calculated sedimentation rate for this selected interval drops to an average value of $5 \mathrm{~m} / \mathrm{m}$.y., confirming the rapidly decreasing rate since the mid-Pliocene. Short intervals with more intense condensation or even partial hiatuses during the PL6 interval cannot be excluded.

The results obtained by locating in the hole a set of relatively well calibrated datum levels demonstrate the inadequacy of my systematic (one sample per core), routinely made sampling in the upper Pliocene part of Hole $533 \mathrm{~A}$ for this preliminary report. It thus appears that 1 sample/approximately $16,500 \mathrm{yr}$. has been studied in the interval from Cores 533A-29 up to 12,1 sample/ $50,000 \mathrm{yr}$. from Cores 11 to 7 , and only 1 sample/130,000 yr. from Cores 6 to 3 .

Extreme condensation and hiatuses at the level of the PL6 Zone may also explain apparent anomalies in the stratigraphic distribution of some planktonic foraminiferal species, as stated in Site 533. The most obvious is the absence of Pulleniatina obliquiloculata (known to appear first in the latest Pliocene) below the Quaternary boundary (Figs. 2, 3, 5).

\section{Quaternary}

The boundary between Zones N22 and N23 cannot be directly determined in the Quaternary series of Site 533. Zone 23 has been defined (Blow, 1969) by the occurrence and/or increasing abundance of Globigerina cali$d a$ and Sphaeroidinella dehiscens excavata. The latter is much too sporadic in Hole 533 (only very few and scattered specimens), and in addition the taxa dehiscens s.1. totally disappears above Core 9. Moreover, no significant variation in abundance of the former species has been depicted in the late Pleistocene interval of Hole 533.

Shipboard preliminary investigations suggest a tentative ternary subdivision of the Pleistocene sequence (Site chapter 533, fig. 26 , this volume) on the basis of the Globorotalia tosaensis LAD for the lower first unit and the FAD of Pulleniatina finalis for the upper third unit (cf., Stainforth et al., 1974). More detailed study of a more closely spaced sampling allowed me to detect an earlier first appearance of $P$. finalis, so that in Hole 533, FAD of the latter and LAD of the former species are in fact separated by only a few cores; therefore recognition of the intermediate unit (defined as simultaneously lacking $G$. tosaensis and $P$. finalis) does not seem justified.

The Holocene/Pleistocene boundary has somewhat arbitrarily been set just above the decrease of cooler- 


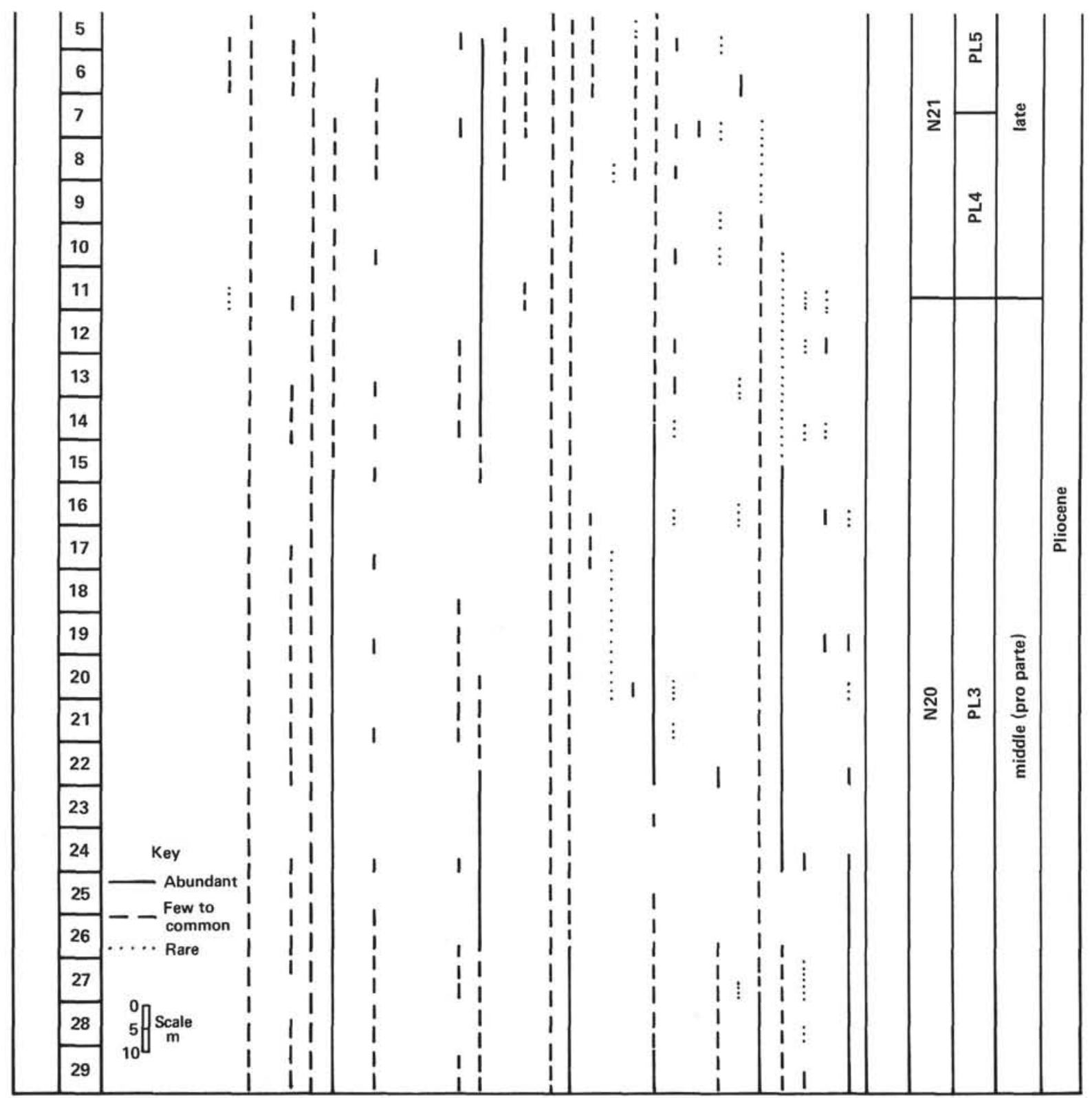

Figure 5. Leg 76, Site 533: stratigraphic range of the most important planktonic foraminifers and biostratigraphic subdivision of the Pliocene-Quaternary. 
water forms, like $G$. inflata, correlative of a drastic increase of warmer-water forms (e.g., G. tumida-menardii complex). In Hole 533 this boundary is located in Core 1, between Samples 533-1-1, 14-16 cm and 533-11, 99-101 cm. In Hole 534 it has been set between Samples 534-1-1, 9-11 cm and 534-1,CC. Study of more closely spaced samples should enable us to determine this boundary more precisely.

Using the "Globorotalia tumida-menardii-ungulata complex" abundance variations, it has been possible, with the "climatic" zonation of Ericson (Ericson and Wollin, 1968), to subdivide in more detail the Quaternary sequence cored at Site 533. In particular, Zones P to $\mathrm{V}$ appear to be clearly identifiable in Hole 533 (Fig. 5). Exact delineation of Zones $\mathrm{W}$ to $\mathrm{Z}$ is slightly more difficult on the basis of my first biostratigraphic sampling, and has been more easily deduced from the more closely spaced "paleoclimatic" sampling (see Fig. 9).

Approximate ages for faunal boundaries delineating these zones have been previously estimated in tropical Atlantic latitudes, for instance, by Briskin and Berggren (1975) and others (e.g., Ericson and Wollin, 1968). These data are compiled and compared to corresponding subbottom depths in Hole 533 (Table 2).

Plotting values of sub-bottom depths of Ericson's zonal boundaries (as recognized in Hole 533) versus time (Fig. 6) results in a curve showing more detailed variations of the sedimentation rate in this area during the Quaternary period. With some reservations (taking into account the various degrees of approximation intervening at each stage of the processing), we may interpret this curve to identify two short periods during which the sedimentation rate declined to a minimum value of about $30 \mathrm{~m} / \mathrm{m} . \mathrm{y}$. One period includes Zones $\mathrm{W}$ and $\mathrm{X}$, near the top of the Pleistocene; the other corresponds to the interval extending from the Pliocene/Quaternary boundary up to the lower limit of Zone P. In addition, the shape of the curve shows that the extreme sedimentary condensation of the latest Pliocene episode was succeeded during the early Pleistocene by a progressive increase of the sedimentation rate, which accelerated dur-

Table 2. Approximate ages for Quaternary faunal boundaries.

\begin{tabular}{ccc}
\hline Faunal boundary & $\begin{array}{c}\text { Approximate } \\
\text { age (in m.y.) }\end{array}$ & $\begin{array}{c}\text { Sub-bottom depth in } \\
\text { Hole 533 (m) }\end{array}$ \\
\hline Y/Z & 0.011 & 1 \\
X/Y & 0.070 & 3.5 \\
W/X & 0.130 & 6.5 \\
V/W & 0.175 & 8.5 \\
U/V & 0.440 & 29.5 \\
T/U & 0.535 & 42.0 \\
S/T & 0.995 & 71.5 \\
R/S & 1.250 & 90.5 \\
Q/R & 1.565 & 127.0 \\
P/Q & 1.630 & 139.5 \\
P (lower) & 1.750 & 148.0 \\
Pliocene/Quaternary & 1.850 & 151.0 \\
boundary & & \\
\hline
\end{tabular}

Note: Data are synthesized from Ericson and Wollin (1968), Briskin and Berggren (1975), Haq et al. (1977), and Berggren et al. (1980).

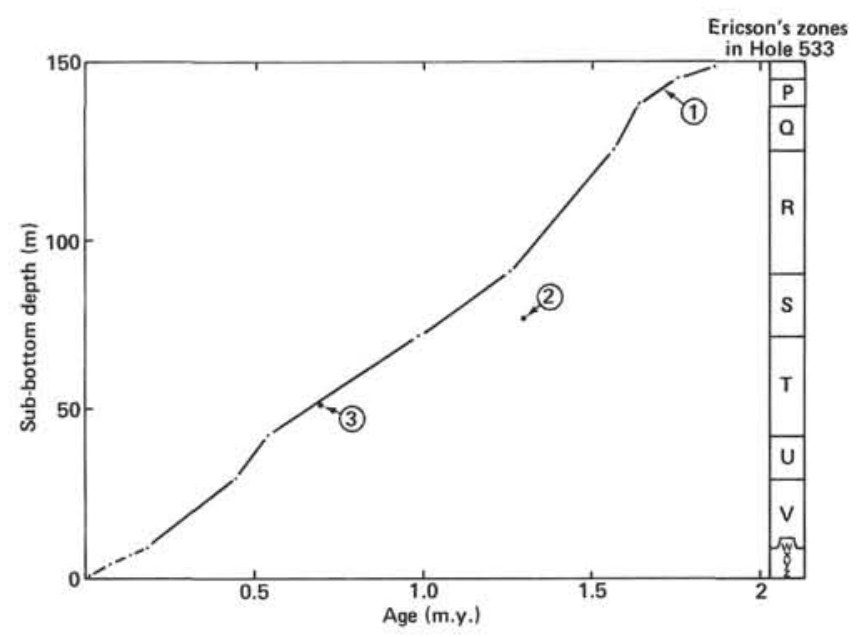

Figure 6. Sub-bottom depths of Ericson's faunal boundaries in Hole 533 plotted versus time. (The resulting curve shows variations of the Quaternary sedimentation rate [arbitrarily assumed to be constant in each of Ericson's zonal intervals]. 1 = Globigerinoides obliquus LAD; 2 = Pulleniatina finalis FAD; 3 = Matuyama/Brunhes boundary.)

ing Zone Q to slightly more than $200 \mathrm{~m} / \mathrm{m}$.y. and then slowed again, closer to the average value of $\pm 80 \mathrm{~m} / \mathrm{m}$.y. However, the curve of Figure 6 still depicts some further fluctuations, with a faster sedimentation rate during Zones $\mathrm{R}$ and $\mathrm{U}$, and rates closer to the average value just cited above, in Zones $\mathrm{S}, \mathrm{T}, \mathrm{V}, \mathrm{Y}, \mathrm{Z}$.

Because it is possible to identify without too many difficulties Ericson's zones in this series, it can be deduced that sedimentary processes should not involve major disturbances, important faunal reworkings, or displacements, at least during Zones $\mathrm{Q}$ to $\mathrm{V}$. The post-V sequence, during which sedimentation rate slightly declined, shows a less clear pattern. Problems arise, owing to the abnormal occurrence of Globorotalia tumida flexuosa in two samples (533-1-1, 2.5-3.5 cm and 534-1$1,9-11 \mathrm{~cm}$ ), both very close to the sea bottom and attributable to Zone Z. An age of circa $0.011 \mathrm{~m}$.y. is attributed to the lower limit of this zone (Broecker et al., 1960), whereas $G$. tumida flexuosa is known to last appear 0.1 m.y. ago in the Atlantic Ocean (see Table 2).

Three other foraminiferal datum levels give additional control to the slope of the curve shown in Figure 6:

1) Globigerinoides obliquus LAD (1.7 m.y.), which was observed in Hole 533 at a sub-bottom depth of 145 m (Sample 533-35,CC);

2) Pulleniatina finalis FAD (1.3 m.y.), here depicted at $77 \mathrm{~m}$ but in a zone of very scattered occurrence;

3) Matuyama/Brunhes paleomagnetic boundary $(0.69$ m.y.), the equivalent of which is evidenced by the extinction of a group of benthic foraminifers below Sample 533-14,CC (sub-bottom depth $51.5 \mathrm{~m}$.) (Blanc-Vernet, this volume).

Datum levels 1 and 3 fall exactly on the curve based on Ericson's zonal boundaries, whereas datum level 2 is offset (Fig. 6). The presence of $P$. finalis is very sporadic in Hole 533, and its first appearance cannot be used here as a significant datum. 


\section{PALEOCLIMATOLOGY AND PALEOCEANOGRAPHY}

A quantitative analysis of planktonic foraminifers has been conducted at Site 533, including a calculation of abundance percentages at the species level (or groupings of a few related species), determination of the predominant coiling direction among populations of Globorotalia truncatulinoides (in the Quaternary), and a study of the variations of several parameters among populations of the genus Orbulina (in the uppermost Quaternary only).

Three distinct test intervals were investigated: (1) Holocene and uppermost Pleistocene Cores 533-1 to 5; (2) lowermost Pleistocene to uppermost Pliocene Cores 53337 to 41 ; and (3) mid-Pliocene Cores 533A-26 to 29.

\section{Global Quantitative Characteristics of Selected Samples}

Percentages in weight of the $\geq 63-\mu \mathrm{m}$ washed residue, as well as the number of foraminifers per gram of dried sample, the number of benthic specimens per gram of dried sample, and the percentages of planktonics of selected samples from the three tested intervals are plotted in Figure 7. A comparison of the variations in these various parameters provide information on sedimentary process changes.
The low percentages of residue as well as the scarcity of both planktonic and benthic foraminifers in Cores 533A-26 to 29 (test interval no. 3, bottom of Zone PL3) may be correlated with the extremely high sedimentation rate $(570 \mathrm{~m} / \mathrm{m} . \mathrm{y}$.) prevailing at that time, during which foraminifers appear to have been strongly "diluted" in sediment predominantly composed of fine ( $\leq 63$ $\mu \mathrm{m})$ terrigenous material.

In Cores 533-41 to 37 (test interval no. 2), Samples 533-41-3, 27-29 cm to 533-38-3, 25-27 cm (upper PL5 Zone) reveal an increased percentage of the $\geq 63-\mu \mathrm{m}$ residue compared to interval no. 3 , without any correlative enrichment in foraminifers, whose abundance values (for both total foraminifers and benthics) remain equal to or slightly higher than those obtained in the PL3 interval. This fact suggests some decrease of foraminiferal productivity at this level, more important for planktonics than for benthics.

The data then show an abrupt change in Zone PL6 (Core 38, Section 2) and the basal Quaternary (Core 38, Section 1, Core 38X, Core 37) intervals. There is evidence of strong condensation, with an almost simultaneous increase of planktonics and benthics. Following a period of maximum condensation straddling the Pliocene/Quaternary boundary, there is a reversal trend appearing in Core 37, which corresponds well with the ba-

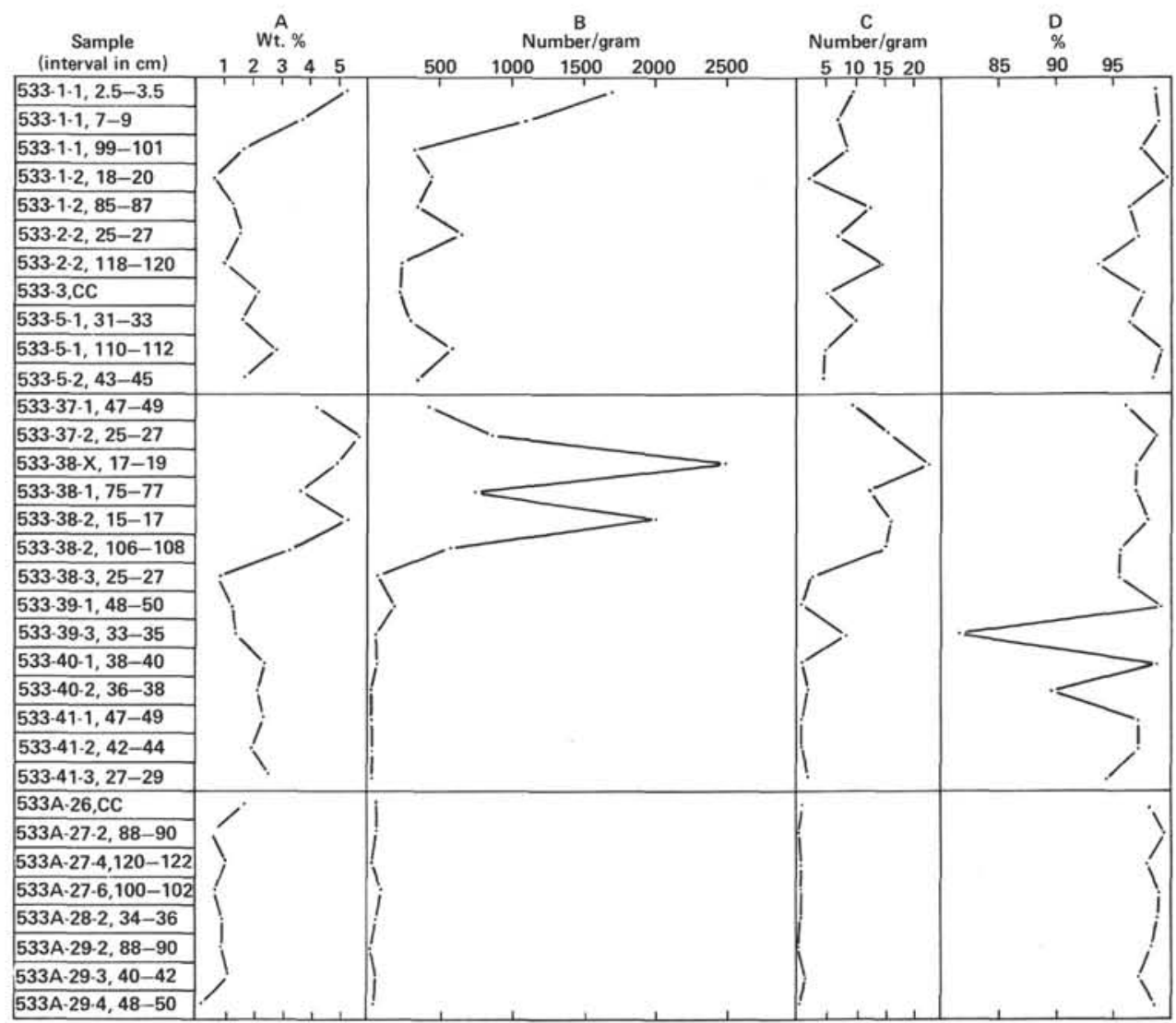

Figure 7. Global quantitative characteristics of selected samples from three test intervals (Cores 533-1 to 5; 533-37 to 41 ; 533A-26 to 29 ). $\mathrm{A}=$ percentage in weight of $\geq 63-\mu \mathrm{m}$ residue. $\mathrm{B}=$ number of foraminifers per gram of sediment, $\geq 160-\mu \mathrm{m}$ size fraction. $\mathrm{C}=$ number of benthic foraminifers per gram of sediment, $\geq 160-\mu \mathrm{m}$ size fraction. $\mathrm{D}=$ percentage of planktonic foraminifers in the $\geq 160-\mu \mathrm{m}$ size fraction. 
sal Pleistocene part of the sedimentation rate curve depicted in Figure 6.

The uppermost Pleistocene-Holocene interval (Hole 533 , Cores 1-5) seems to be characterized by a more important planktonic foraminiferal productivity than the deeper intervals. Some sedimentary processes resulting in concentration of microfossils could also affect this part of the series, particularly Samples 533-1-1, 7-9 cm and 533-1-1, 2.5-3.5 cm, located near the top of Core 1 . Such concentration does not appear to correspond strictly with the fluctuations of the sedimentation rate curve (Fig. 6).

\section{Detailed Analysis of Test Intervals}

\section{Test Interval No. 1}

Calculated percentages of some representative planktonic species (Fig. 8) and cumulative percentages (Fig. 9) show that the planktonic assemblage at the top of Hole 533 is climatically typical of the subtropical province (cf., Be, 1977). This attribution is based on the abundance of Globigerinoides ruber, which ranks here as the dominant species, followed by Globorotalia truncatulinoides and Globigerinoides quadrilobatus s.l. (= G. sacculifer sensu Bé), and on the absence of "Globigerina" pachyderma. More precisely, this Holocene assemblage appears to belong to the rather cooler area of the subtropical province, with some affinities to the transition zone that are momentarily accentuated in intervals of the Pleistocene during the colder parts of the climatic cycles. This is evidenced by sharp increases in the percentage of Globorotalia inflata, which in some periods (for instance, during Zones $\mathrm{Y}$ and $\mathrm{W}$ ) may rank in frequency as the second species in the planktonic assemblage.
There is a distinct inverse correlation between the relative abundances of $G$. inflata and $G$. truncatulinoides, reflecting climatic variations. Variations of coiling in the latter species are also significant but more difficult to interpret. Sinistrally coiled forms of $G$. truncatulinoides are normally predominant in the "warm" Holocene (Lutze et al., 1979), but (as expected) drop to almost zero during the cold cycle of Zone $\mathrm{Y}$, which is also characterized by a significant increase in the percentage of $G$. inflata. Below the X/Y boundary, the pattern becomes slightly less clear. Sinistral forms remain very poorly represented during Zone X (which is nevertheless affected by a slight warming) and the top of Zone W (a cold period), and raise again in percentage, predominating more or less erratically on dextral forms in the lower part of Zone $\mathrm{W}$ and the top of Zone $\mathrm{V}$ (warmer).

The peak of $35 \%$ reached by Globigerinoides ruber during the coldest period of Zone Y (Sample 533-1,CC) could be better explained by influence of salinity than by surface water temperature (cf., Briskin and Berggren, 1975; Bé, 1977).

Detailed variations in abundance percentages shown by other forms like Pulleniatina spp., Globoquadrina dutertrei, Globigerinella-Hastigerinella group and, surprisingly, by Globigerinoides quadrilobatus s.1., as well as variations of diameter measured in Orbulina (Fig. 10), do not appear significant nor do they clearly correlate to the climatic trends inferred from Globorotalia. This apparently discordant pattern should be brought together with another anomaly that has been mentioned above, that is, the higher occurrence of G. tumida flexuosa in the tops of Holes 533 and 534; these occurrences could be considered as additional evidence of consequences of more or less small-scale microfaunal reworkings and/or displacements, thus slightly obscuring the stratigraphic

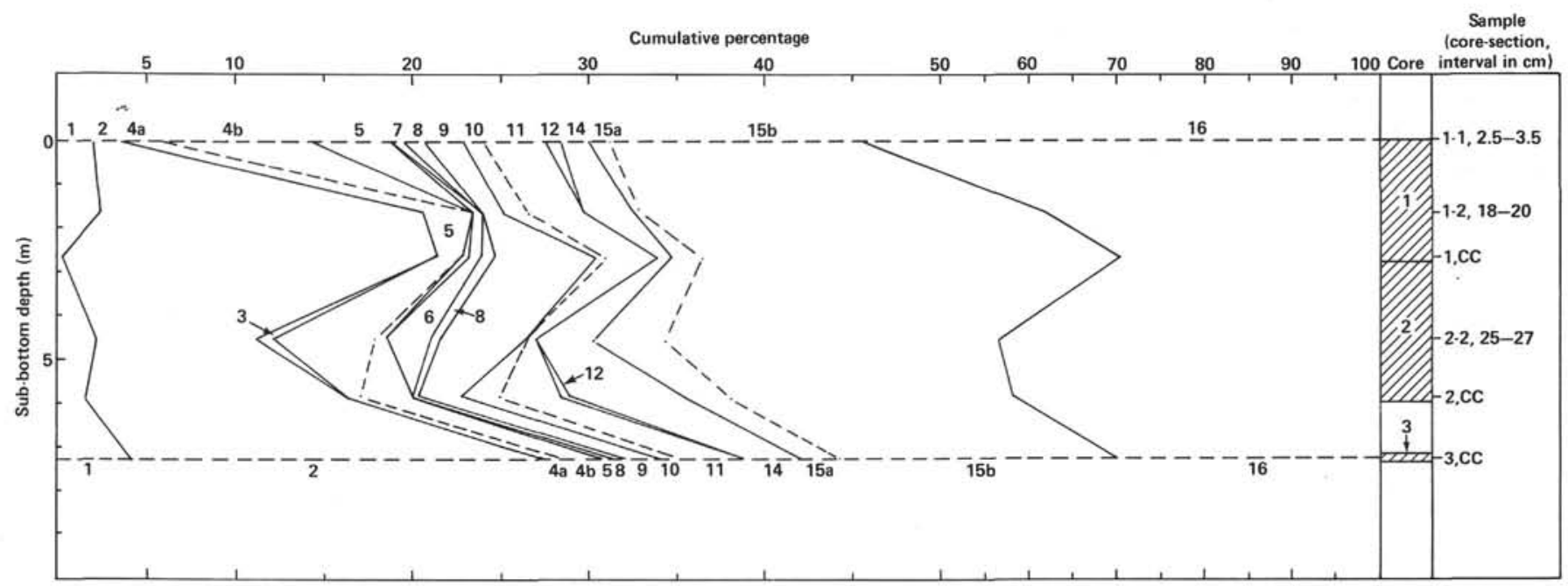

Figure 8. Variation in the cumulative percentage of planktonic foraminiferal species or groups from the top interval of Hole 533 (Cores 1-3, Holocene and uppermost Pleistocene). ( $1=$ Orbulina; $2=$ Globorotalia inflata; $3=G$. gr. crassaformis; $4=G$. truncatulinoides [a, dextral; b, sinistral]; $5=G$. hirsuta; $6=G$. scitula; $7=$ menardiiform globorotalids [G. tumida, G. menardii, G. ungulata]; $8=P$ Pulleniatina $[P$. obliquiloculata, $P$. finalis]; 9 = Globoquadrina dutertrei; $10=$ Globigerinoides quadrilobatus sacculifer; $11=G$. quadrilobatus trilobus; $12=G$. conglobatus; 13 = Sphaeroidinella dehiscens; 14 = Globigerinella/Hastigerinella group; 15 = Globigerinoides ruber [a, pink; b, colorless]; $16=$ uther species [undifferentiated].) 


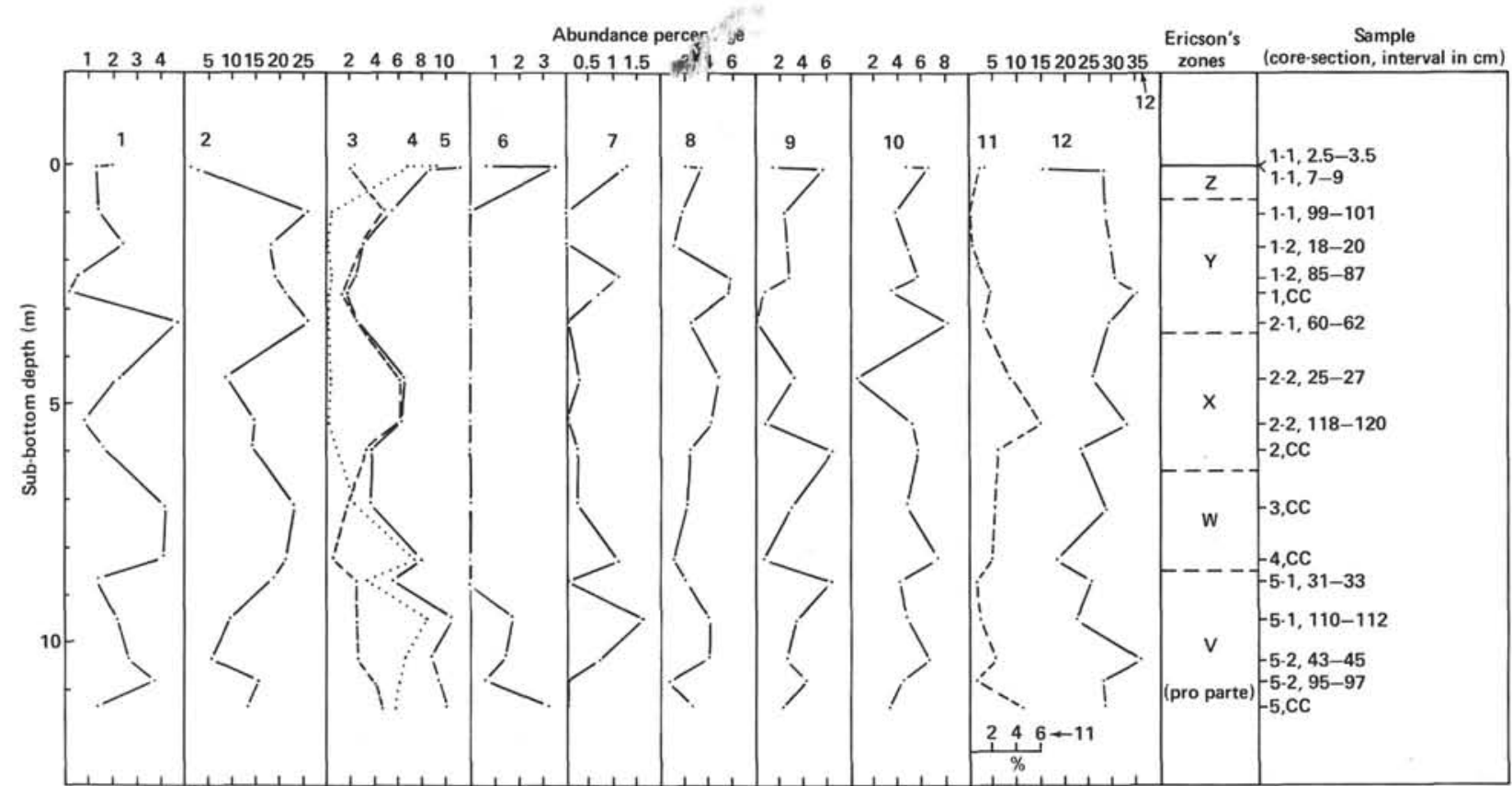

Figure 9. Percent abundances of selected planktonic foraminiferal species in the $\geq 160-\mu \mathrm{m}$ planktonic assemblages (Holocene-uppermost Pleistocene, test interval no. 1 -Cores 533-1 to 5). $(1=$ Orbulina; $2=$ Globorotalia inflata; $3-5=$ G. truncatulinoides [3, dextral; 4 , sinistral; 5, total percentage); $6=$ menardiiform globorotalids; $7=$ Pulleniatina; $8=$ Globoquadrina dutertrei; $9=$ Globigerinella-Hastigerinella; $10=$ Globigerinoides quadrilobatus s.1.; 11-12: G. ruber [11, pink; 12, total percentage].)

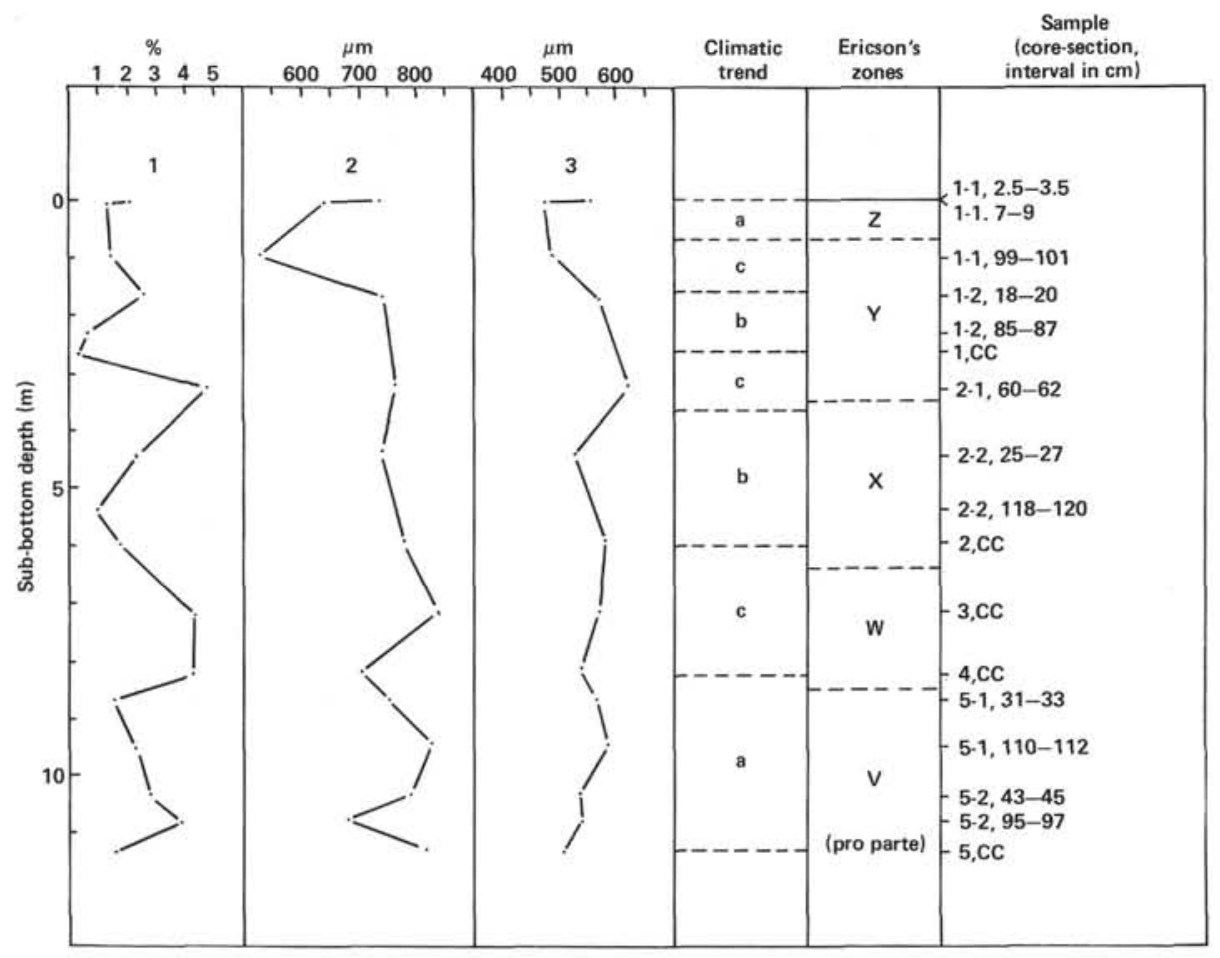

Figure 10. Genus Orbulina-variation of several parameters (test interval no. 1, Cores 533-1 to 5, Holocene-uppermost Pleistocene). ( 1 = percent abundance; 2 = maximum values of the diameter; 3 = mean values of the diameter. Climatic trends mostly deduced from variations of percent abundances of Globorotalia inflata, G. truncatulinoides, and menardiiform globorotalids [see Fig. 9]; $\mathrm{a}=$ warmer; $\mathrm{c}=$ cooler; $\mathrm{b}=$ intermediate.) 
and mostly the paleoclimatic signal. Poag (1972) has also observed some mixing of Holocene and uppermost Pleistocene sediments at the top of DSDP Holes 103 and 104, immediately south of Site 533 .

\section{Test Interval No. 2}

Assemblages in this lowermost Pleistocene-uppermost Pliocene interval are also representative of the subtropical province, with, however, subtropical characteristics slightly more accentuated than in the Holoceneuppermost Pliocene assemblages. Percentages of Globigerinoides ruber (grouped here with G. gr. obliquus) are more sharply predominant; G. quadrilobatus s.l., menardiiform globorotalids, and Globigerinoides conglobatus are also statistically better represented here than in the test interval no. 1 . On the whole, percentages of Globorotalia inflata do not exceed 5 to $6 \%$ here, except for a short interval with a $20 \%$ peak in Sample 533$37-1,47-49 \mathrm{~cm}$. Other parameters do not suggest that this peak corresponds to a significantly colder episode.
Variations in the abundance of planktonic foraminiferal species throughout the interval (Figs. 11-12) do not show clear paleoclimatic and paleoceanographic trends. Like Briskin and Berggren (1975) did in slightly more southern latitudes, I have observed in the basal Pleistocene of Site 533 inconsistencies in abundance curves for Globigerinoides quadrilobatus s.1. (= G. sacculifer + G. trilobus) and G. ruber, which vary either (most often) inversely or (more rarely) in phase. Fluctuations in the abundance of G. quadrilobatus sacculifer are interpreted as probably linked to temperature variations and those of $G$. ruber to salinity variations. The sampling density used for this quantitative study (one sample per section) may not be sufficient enough to reveal details of paleoclimatically induced oscillations in this highly condensed stratigraphic interval. Finally, we have also to face the possibility that as in test interval no. 1, the paleoclimatic signal is more or less obscured by small-scale reworkings and mixtures of sediments and microfaunas, for instance, as a result of bottom contour-following currents.

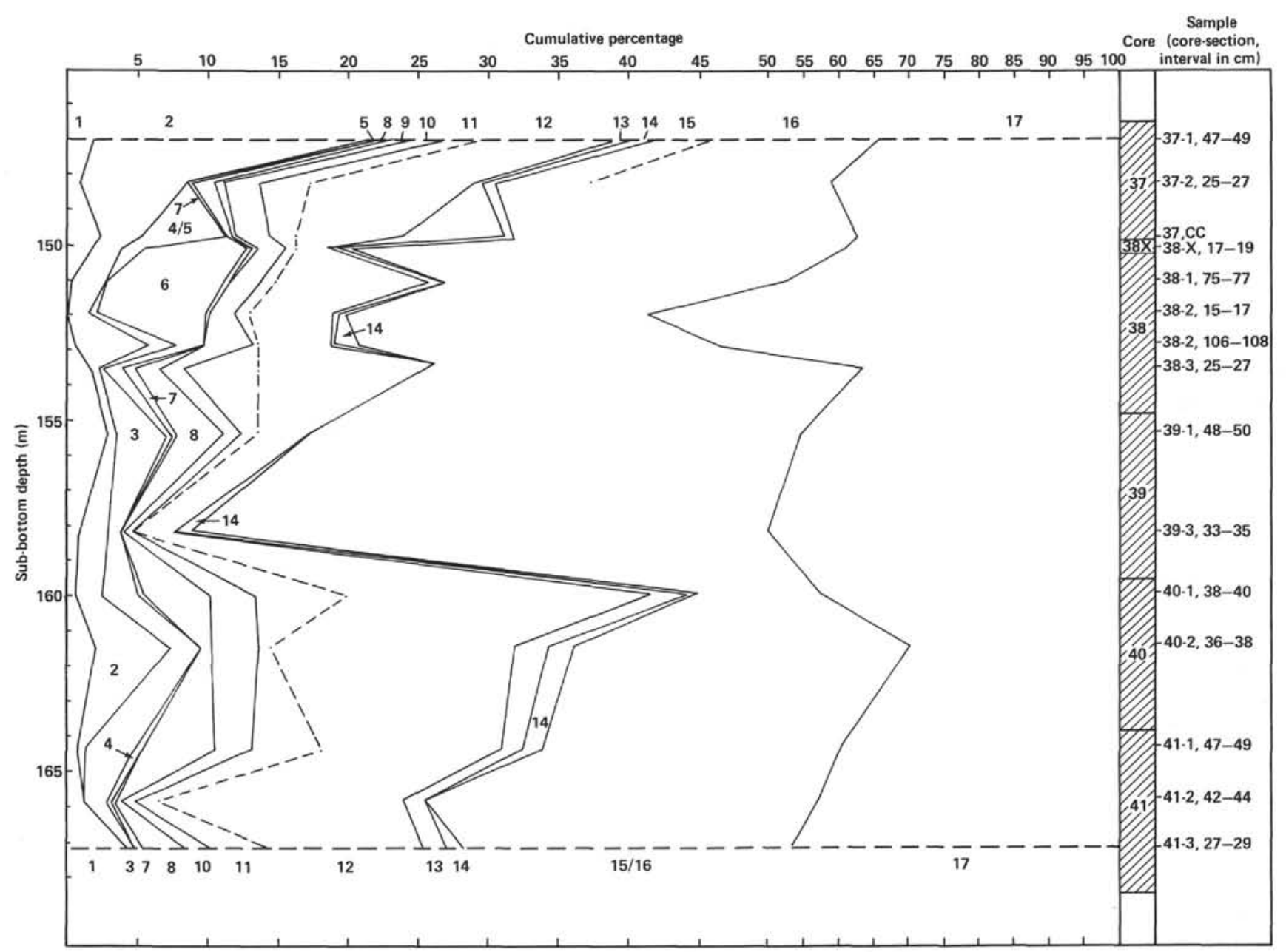

Figure 11. Variation in the cumulative percentage of planktonic foraminiferal species or groups from the uppermost Pliocene-lowermost Pleistocene interval (Cores 533-37 to 41$)$. $(1=$ Orbulina; $2=$ Globorotalia inflata; $3=G$. gr. crassaformis; $4=G$. tosaensis; $5=G$. truncatulinoides; $6=G$. hirsuta; $7=G$. scitula; $8=$ menardiiform globorotalids; $9=$ Pulleniatina; $10=$ Globoquadrina gr. acostaensis-humerosa-dutertrei; 11 = Globigerinoides quadrilobatus sacculifer; $12=$ G. quadrilobatus trilobus; $13=$ G. conglobatus; $14=$ Sphaeroidinella dehiscens (s.1.); $15=$ G. gr. obliquus; $16=G$. ruber; $17=$ other species.) 


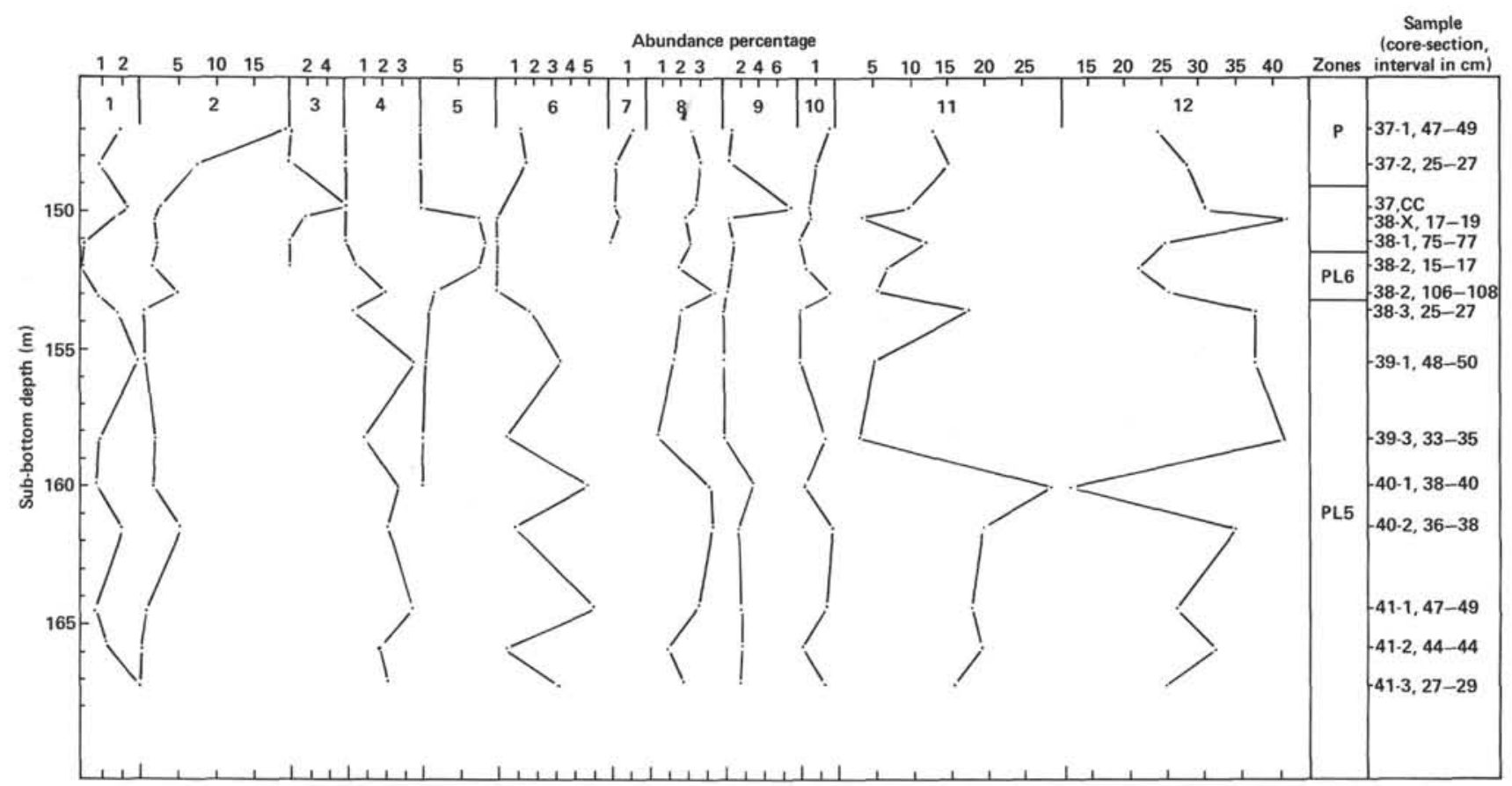

Figure 12. Percent abundances of selected planktonic foraminiferal species (uppermost Pliocene-lowermost Pleistocene, test interval no. 2 (Cores 533-37 to 41$)$. $(1=$ Orbulina; $2=$ Globorotalia inflata; $3=G$. truncatulinoides; $4=G$. gr. crassaformis; $5=G$. hirsuta; $6=$ menardiiform globorotalids; 7 =Pulleniatina; $8=$ Globoquadrina gr. acostaensis-humerosa-dutertrei; $9=$ Globigerinoides conglobatus; $10=$ Sphaeroidinella dehiscens (s.l.); $11=$ G. quadrilobatus (s.1.); $12=$ G. gr. ruber-obliquus.)

\section{Test Interval No. 3}

In this interval of extremely high sedimentation rate density of sampling should be more favorable than in other intervals. The data (Figs. 13-14), however, are still not easy to decipher. Abundance curves of Globigerinoides obliquus-ruber and of G. quadrilobatus s.l. show the same general opposite trends. The shape of the curves in the Core 29 interval may denote a warmer episode in the upper and middle part of the core, and then a distinct cooling in the bottom, at the level of Sample $533 \mathrm{~A}-29, \mathrm{CC}$. The interval from Core 26 to Core 28 seems to correspond to more stable climatic conditions, without any well characterized cycle or episode. The lower part of Core 27 (Sections 4-6) may coincide with cooler conditions, as evidenced by a simultaneous decrease in percentages of G. quadrilobatus s.1., Sphaeroidinellopsis spp., G. conglobatus, and menardiiform globorotalids. However, at this same level the relative abundance of Orbulina and the rarity of Globorotalia puncticulata (supposed to show the same climatic response as its phylogenetic successor $G$. inflata) do not particularly strengthen this tentative interpretation.

\section{CONCLUSION}

Detailed investigations based on planktonic foraminiferal distribution enabled us to establish a zonal subdivision of the Pliocene-Quaternary series at Site 533, which permitted us to estimate the sedimentation rate fluctuations and to identify wide-scale climatic cycles (like those defining Ericson's zones in the Quaternary) but did not allow us to follow in great detail short periodic episodes, even using quantitative methods. A care- ful examination of the planktonic foraminiferal distribution led us also to believe that another major climatic event may have occurred in the upper part of the middle Pliocene. The sequence from Cores 533A-29 up to 19 seems to represent a globally relatively warm interval (given the relative abundance of keeled species, Sphaeroidinellopsis, Globoquadrina gr. altispira, Globigerinoides quadrilobatus s.1., and so on). The next sequence approximately including Cores $533 \mathrm{~A}-18$ to 11 , is marked by a sharp decrease or even complete disappearance of several warmer-water indicators, and by the reappearance of Globorotalia puncticulata. This apparently colder interval chronologically extends from about 3.2 or 3.1 to $3.0 \mathrm{Ma}$, and could denote the repercussions of the first "glacial" events that affected the North Atlantic oceanic realm in the Neogene (Berggren, 1972), notwithstanding the divergent opinion of Backman (1979) and Morner and Backman (1980), who believe that this phenomenon did not take place until about 2.5 Ma. At Site 533 this latter period (circa $2.5 \mathrm{Ma}$ ) does not appear to be marked by any important change other than a strong although progressive increase of the sedimentary condensation processes, without any clear alteration of the climatic signal.

\section{ACKNOWLEDGMENTS}

I wish to express my gratitude to my colleagues Dr. France Irr and Dr. Pierre Saint-Marc (University of Nice, France), Dr. Roger Anglada (University of Marseille, Saint-Charles, France), Dr. Laure BlancVernet (University of Marseille-Luminy, France), Dr. James Ogg (University of Wyoming), Dr. Edith Vincent (Scripps Institution of Oceanography), Dr. Felix Gradstein (Atlantic Geoscience Centre, Dartmouth, Canada) and Dr. William A. Berggren (Woods Hole Oceanographic Institution), who critically read first versions of this manu- 


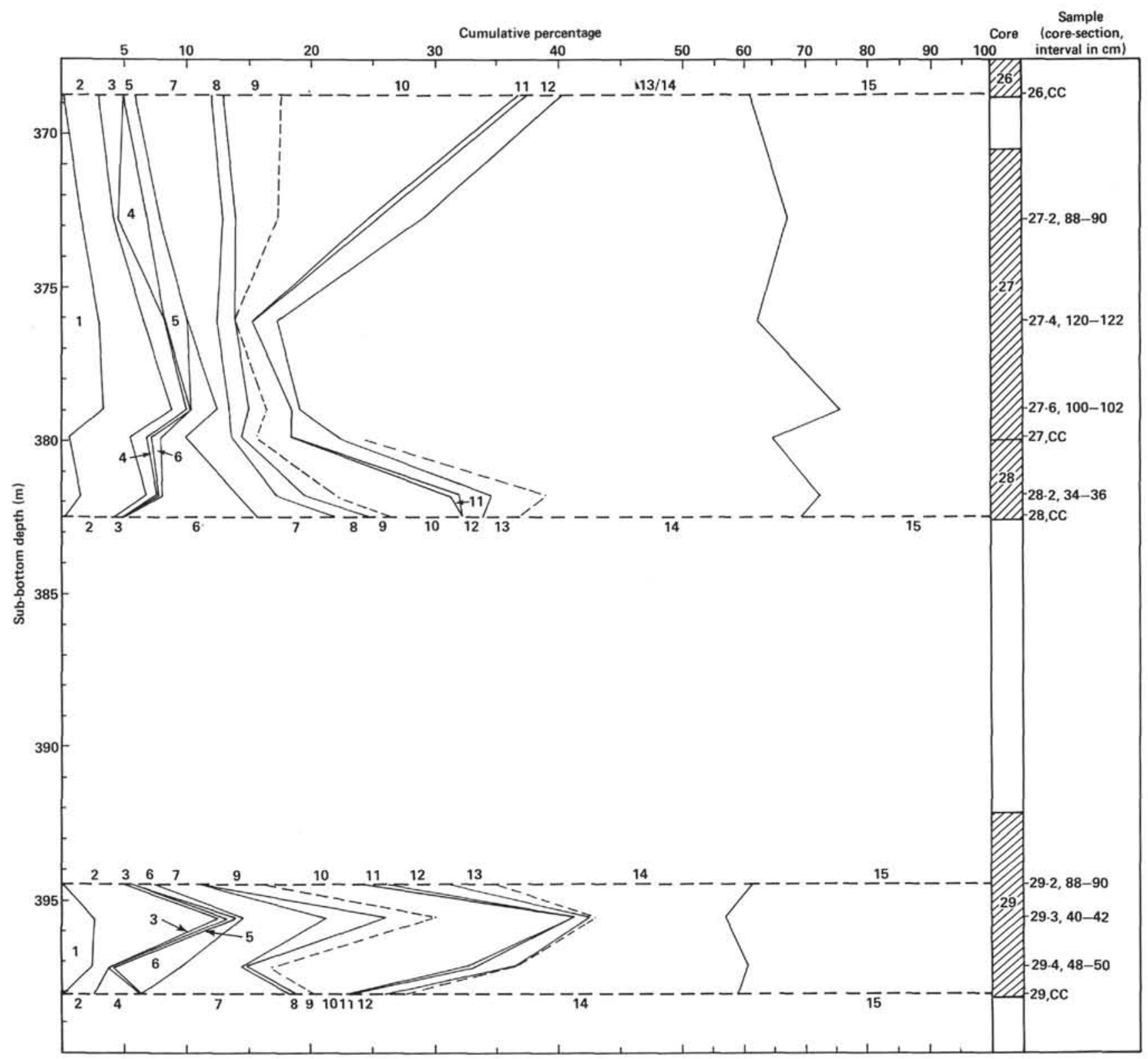

Figure 13. Variation in the cumulative percentage of planktonic foraminiferal species or groups from the deepest interval of Hole 533A (Cores 26-29, middle Pliocene). $(1=$ Orbulina; $2=$ Globoquadrina gr. altispira; $3=$ Globorotalia gr. crassaformis; $4=G$. puncticulata; $5=G$. scitula; $6=$ G. praehirsuta; $7=$ menardiiform globorotalids; $8=$ Globoquadrina gr. acostaensis-humerosa; $9=$ Globigerinoides quadrilobatus sacculifer; $10=$ G. quadrilobatus trilobus; $11=$ G. conglobatus; $12=$ Sphaeroidinellopsis spp.; $13=G$. ruber; $14=G$. gr. obliquus-extremus; 15 = other species.)

script and made valuable suggestions and comments. The plates were photographed with a JEOL JSM2 SEM at the University of Marseille, Saint-Charles (France) thanks to the assistance of Dr. R. Anglada and Mrs. C. Roland.

I thank DSDP for inviting me to participate in Leg 76 of the Project and the Centre National pour l'Eploitation des Océans (CNEXO), which provided assistance for travel expenses. Financial support for this investigation was provided by the Centre National de la Recherche Scientifique under Grant ATP Géologie-Géophysique des Océans No. 096.

\section{REFERENCES}

Backman, J., 1979. Pliocene biostratigraphy of DSDP Sites 111 and 116 from the North Atlantic Ocean and the age of Northern Hemisphere glaciation. Stockholm Contrib. Geol., 32:115-137.

Bé, A. W. H., 1977. An ecological, zoogeographic and taxonomic review of Recent planktonic Foraminifera. In Ramsay, A. T. S.
(Ed.), Oceanic Micropaleontology (Vol. 1): London (Academic Press), 1-100.

Berggren, W. A., 1972. Late Pliocene-Pleistocene glaciation. In Laughton, A. S., Berggren, W. A., et al., Init. Repts. DSDP, 12: Washington (U.S. Govt. Printing Office), 953-963. 1973. The Pliocene time-scale: calibration of planktonic foraminiferal and calcareous nannoplankton zones. Nature, 243 (5407):391-397.

1977. Late Neogene planktonic foraminiferal biostratigraphy of the Rio Grande Rise (South Atlantic). Mar. Micropaleontol., 2:265-313.

Berggren, W. A., Burckle, L. H., Cita, M. B., Cooke, H. B. S., Funnell, B. M., Gartner, S., Hays, J. D., Kennett, J. P., Opdyke, N. D., Pastouret, L., Shackleton, N. J., and Takayanagi, Y. 1980. Towards a Quaternary time scale. Quat. Res., 13:277-302.

Berggren, W. A., and Van Couvering, J. A., 1974. The late Neogene: Biostratigraphy, Geochronology and Paleoclimatology of the last 
15 million years in marine and continental sequences. Palaeogeogr., Palaeoclimatol., Palaeoecol., 16:1-216.

Blow, W. H., 1969. Late Middle Eocene to Recent planktonic foraminiferal biostratigraphy. In Brönnimann, P., and Renz, H. H. (Eds.), Proc. 1st Int. Conf. Planktonic Microfossils (Vol. 1), Geneva, 1967: Leiden, pp. 199-421.

Bolli, H. M., and Premoli-Silva, I., 1973. Oligocene to Recent planktonic Foraminifera and stratigraphy of the Leg 15 Sites in the Caribbean Sea. In Edgar, N. T., Saunders, J. B., et al., Init. Repts. DSDP, 15: Washington (U.S. Govt. Printing Office), 475-497.

Briskin, M., and Berggren, W. A., 1975. Pleistocene stratigraphy and quantitative paleoceanography of tropical North Atlantic core V 16-205. In Saito, T., and Burckle, L. H. (Eds.), Late Neogene Epoch Boundaries: New York (American Museum of Natural History), 1:167-198.

Broecker, W. S., Ewing, M., and Heezen, B. C., 1960. Evidence for an abrupt change in climate close to 11,000 years ago. Am. J. Sci., 258:429-448.

Ericson, D. B., and Wollin, G., 1968. Pleistocene climates and chronology in deep-sea sediments. Science, 162(3859):1227-1234.

Haq, B. U., Berggren, W. A., and Van Couvering, J. A., 1977. Corrected age of the Pliocene/Pleistocene boundary. Nature, 269: 483-488.

Lutze, G. F., Sarntheim, M., Koopmann, B., Pflaumann, U., Erlenkeuser, H., and Thiede, J., 1979. Meteor cores 12309: late Pleistocene reference section for interpretation of the Neogene of Site 397. In Von Rad, U., Ryan, W. B. F., et al., Init. Repts. DSDP, 47, Pt. 1, Washington (U.S. Govt. Printing Office), 727-739.

Lynts, G. W., 1980. Late Neogene planktonic foraminifers: East Pacific Rise and Galapagos spreading center-Deep Sea Drilling Project Leg 54. In Rosendahl, B. R., Hekinian, R., et al., Init. Repts. DSDP, 54: Washington (U.S. Govt. Printing Office), 487-507.
Mörner, N. A., and Backman, J., 1980. Pliocene stratigraphy and paleoclimatology in Europe in relation to global paleoceanographic changes and the initiation of glaciations. 26th Int. Geol. Congr., Abstracts, Paris, 2: p. 676. (Abstract)

Parker, F. L., 1973. Late Cenozoic biostratigraphy (planktonic Foraminifera) of tropical Atlantic deep-sea sections. Rev. Espan. Micropaleontol., 5:253-289.

1974. Upper Neogene biostratigraphy (planktonic foraminifera) of DSDP Sites 139 and 141. J. Foraminiferal Res., 4:9-15.

Poag, C. W., 1972. Neogene planktonic foraminiferal biostratigraphy of the Western North Atlantic: DSDP Leg 11. In Hollister, C. D., Ewing, J. I., et al., Init. Repts. DSDP, 11: Washington (U.S. Govt. Printing Office), 483-543.

Rögl, F., and Bolli, H. M., 1973. Holocene to Pleistocene planktonic foraminifera of Leg 15, Site 147 (Cariaco Basin [Trench], Caribbean Sea) and their climatic interpretation. In Edgar, N. T., Saunders, J. B., et al., Init. Repts. DSDP, 15: Washington (U.S. Govt. Printing Office), 553-615.

Stainforth, R. M., Lamb, J. L., Luterbacher, H. P., Beard, J. H., and Jeffords, R. M., 1974. Cenozoic planktonic foraminiferal zonation and characteristics of Index forms. Univ. Kans. Paleontol. Contrib., 32:1-425.

Thunnell, R. C., 1981. Late Miocene-early Pliocene planktonic foraminiferal biostratigraphy and paleoceanography of low-latitude marine sequences. Mar. Micropaleontol., 6:71-90.

Vincent, E., 1981. Neogene planktonic foraminifers from the central North Pacific, Deep Sea Drilling Project Leg 62. In Thiede, J., Vallier, T. L., et al., Init. Repts. DSDP, 62: Washington (U.S. Govt. Printing Office), 329-353.

Date of Initial Receipt: August 9, 1982

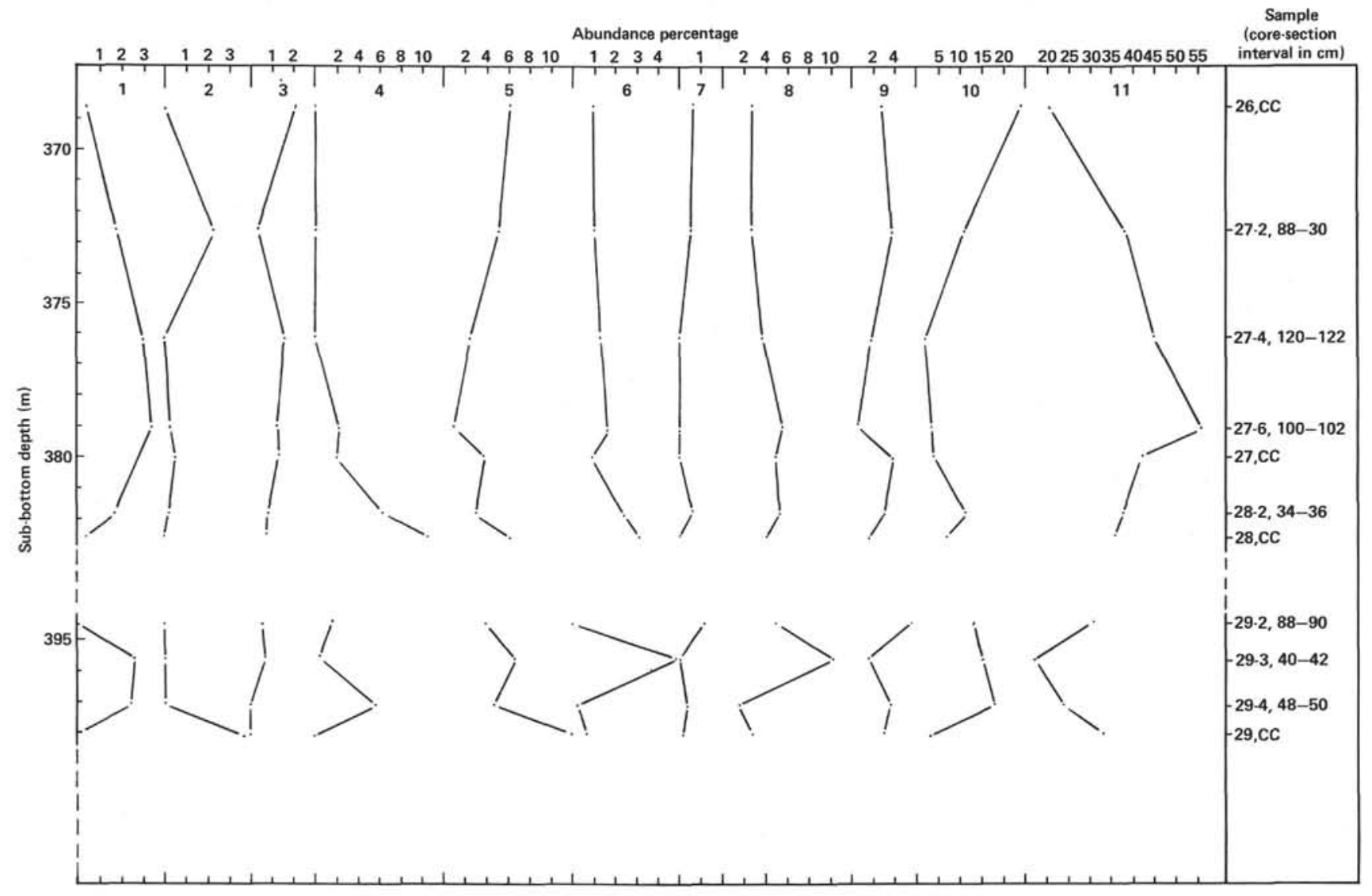

Figure 14. Percent abundances of selected planktonic foraminiferal species (middle Pliocene, test interval no. 3 (Cores $533 \mathrm{~A}-26$ to 29$)$. $(1=\mathrm{Or}$ bulina; $2=$ Globorotalia puncticulata; $3=$ G. gr. crassaformis; $4=G$. praehirsuta; $5=$ menardiiform globorotalids; $6=$ Globoquadrina gr. acostaensis-humerosa; $7=$ Globigerinoides conglobatus; 8: Globoquadrina gr. altispira; $9=$ Sphaeroidinellopsis spp.; $10=$ Globigerinoides quadrilobatus (s.1.); $11=G$. gr. obliquus-ruber.) 

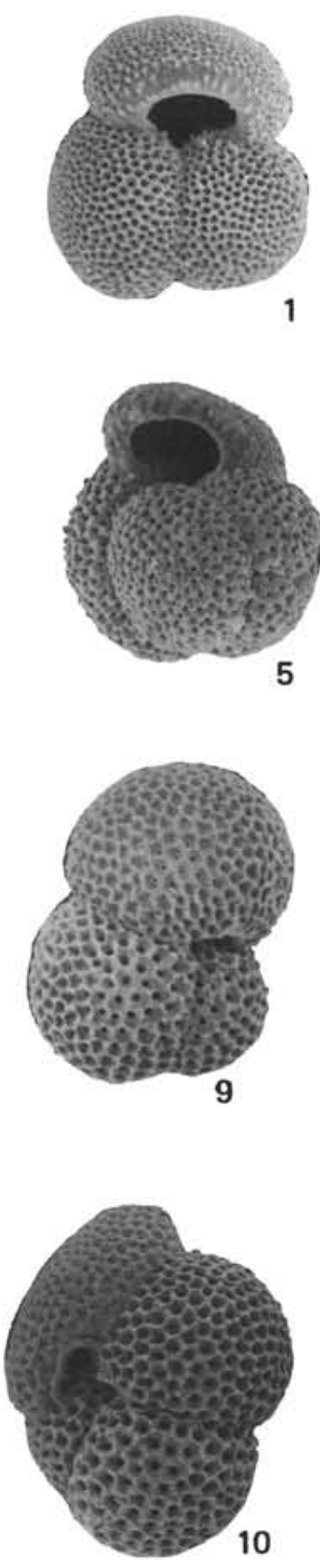
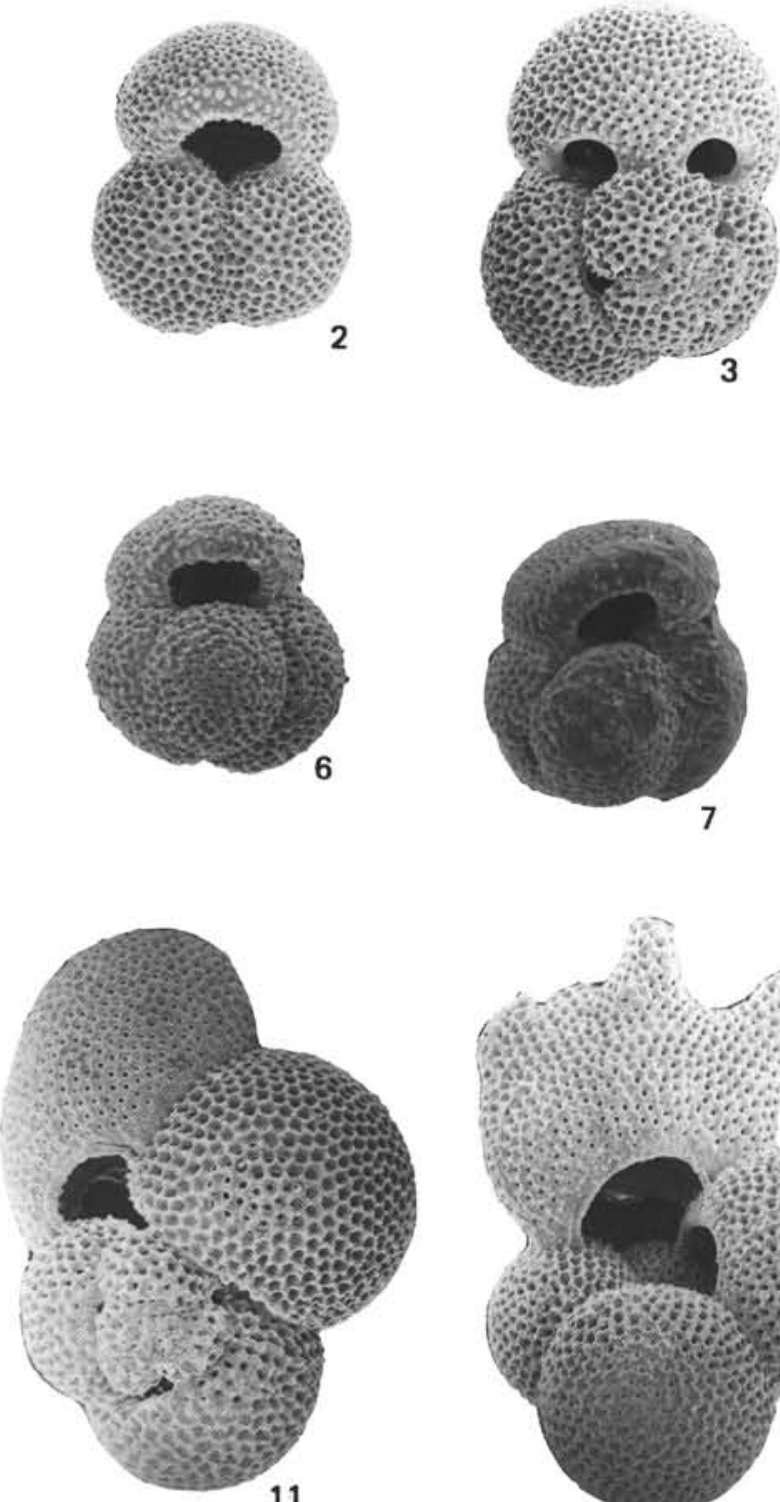

11

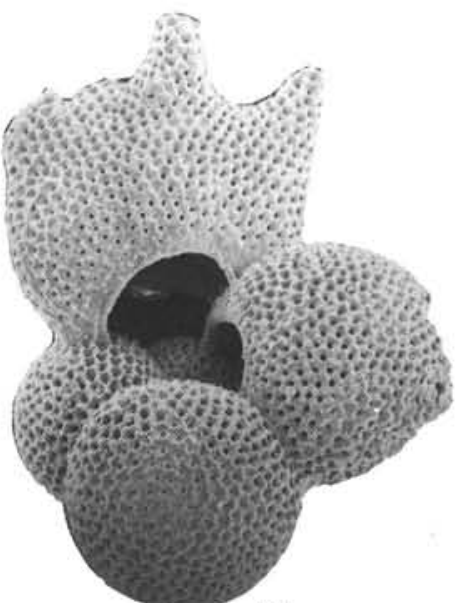

12
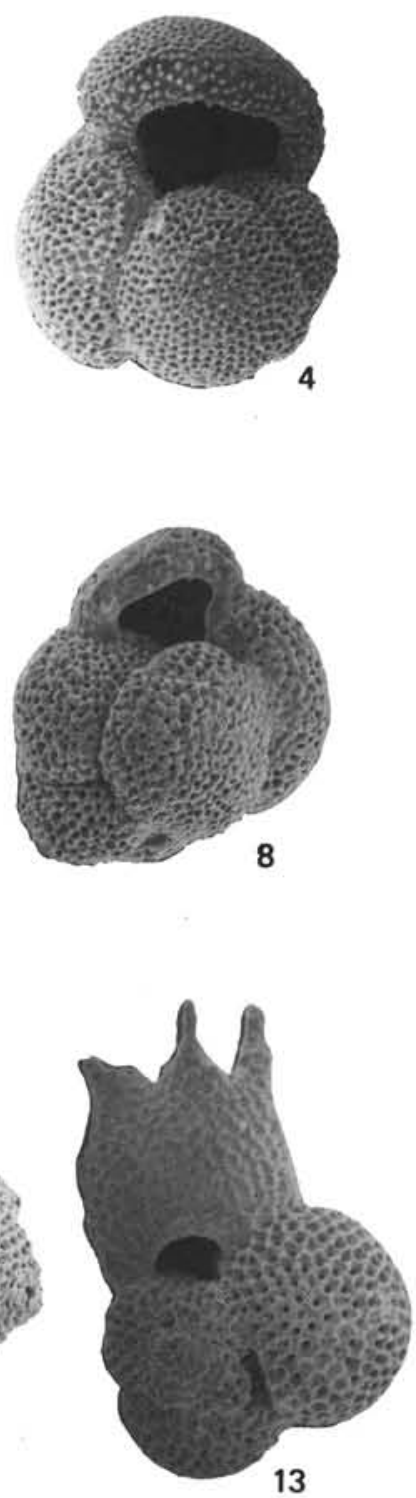

13

Plate 1. Upper Neogene and Quaternary planktonic foraminifers. (All specimens with the exception of Figs. 5-8, 11, and 12 are magnified $\times 82.5$.) 1-3. Globigerinoides ruber (d'Orbigny), (1) umbilical view. Sample 533-26,CC. Lower Pleistocene, (2) umbilical view, (3) spiral view. Sample 533-2-2, 25-27 cm. Upper Pleistocene. 4-8. Globigerinoides gr. obliquus-extremus, (4) umbilical view, (5) umbilical view, $\times 90,(6)$ umbilical view, $\times 90$, (7) umbilical view, $\times 90,(8)$ umbilical view, $\times 90$. Sample 533A-29,CC. Middle Pliocene, Zone PL3. 9. Globigerinoides quadrilobatus trilobus (Reuss), umbilical view. Sample 533-26,CC. Lower Pleistocene. 10-11. Globigerinoides quadrilobatus sacculifer (Brady), (10) umbilical view, (11) spiral view, $\times 78$. Sample 533-26,CC. Lower Pleistocene. 12-13. Globigerinoides quadrilobatus fistulosus (Schubert), (12) umbilical view, $\times 73$, (13) spiral view. Sample 533A-7,CC. Upper Pliocene, Zone PL4. 

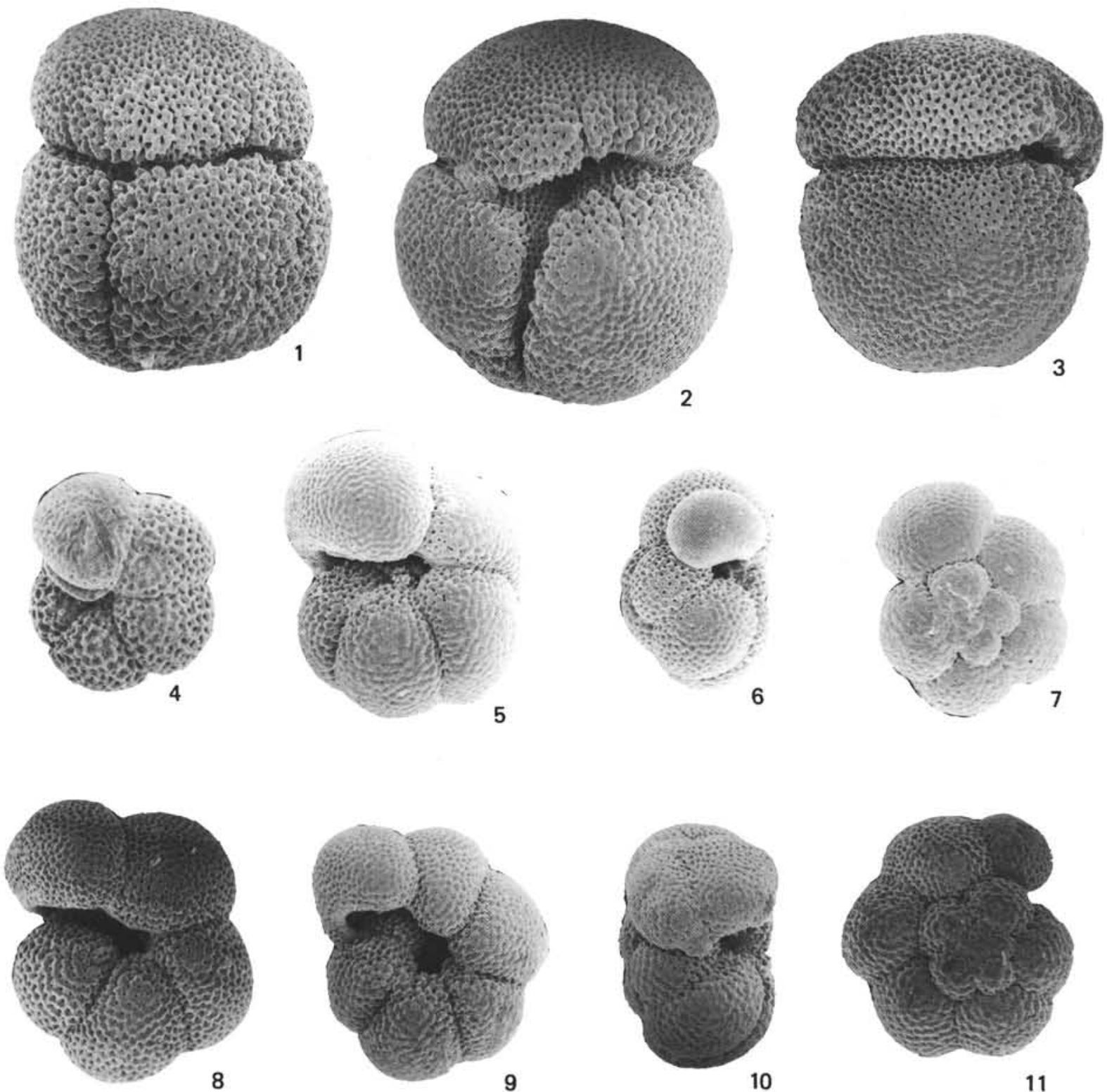

10

Plate 2. Upper Neogene and Quaternary planktonic foraminifers. (All specimens with the exception of Figs. 1-4 are magnified $\times 82.5$ ). 1-3. Globigerinoides conglobatus (Brady), (1) spiral view, $\times 73$, (2) oblique umbilical view, $\times 73$, (3) side view, $\times 73$. Sample 533A-13, CC. Middle Pliocene, Zone PL3. 4. "Globoquadrina" acostaensis (Blow), umbilical view, $\times 127.5$. Sample 533-38-2, 15-17 cm. Late Pliocene, Zone PL6. 58. "Globoquadrina" humerosa (Takayanagi and Saito), (5) umbilical view, (6) side view, (7) spiral view. Sample 533A-18,CC. Middle Pliocene, Zone PL3, (8) umbilical view, Sample 533A-29-3, 40-42 cm. Middle Pliocene, Zone PL3. 9-11. "Globoquadrina"'gr. humerosa-dutertrei, (9) umbilical view, (10) side view, (11) spiral view. Sample 533-38-2, 106-108 cm. Upper Pliocene, Zone PL6. 

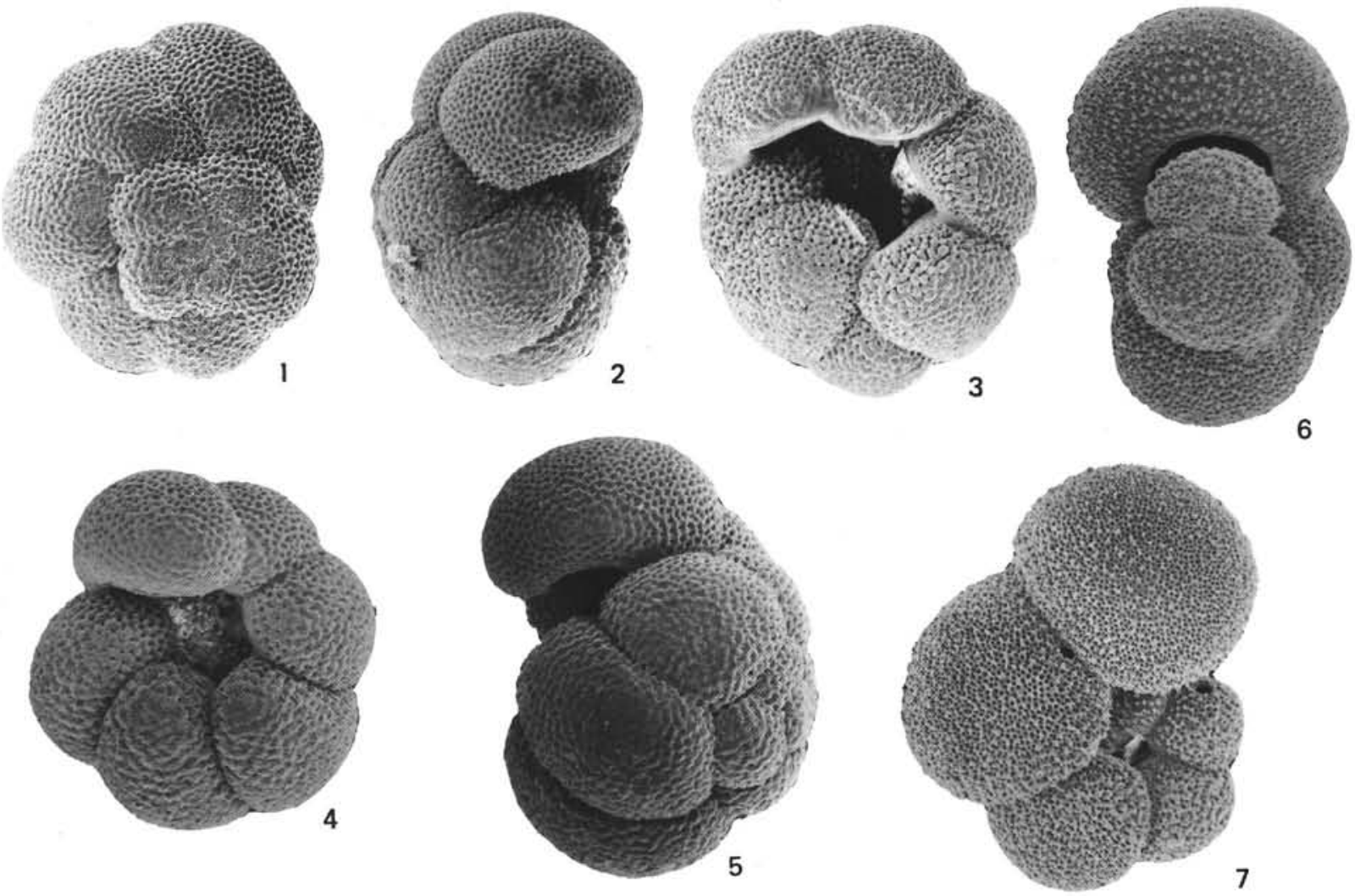

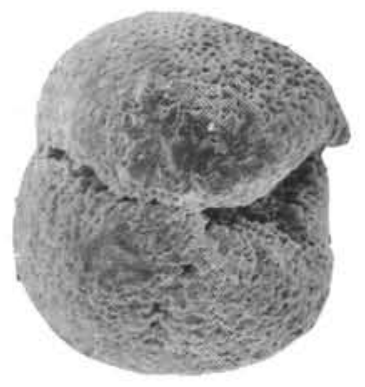

8

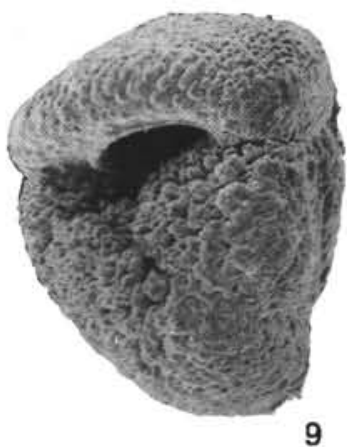

9
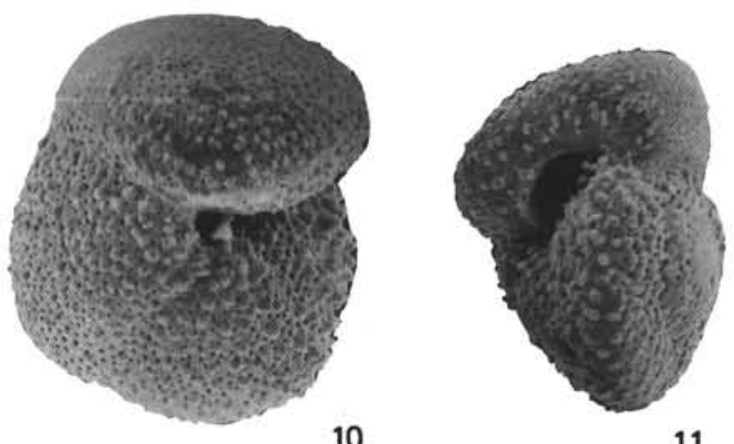

11

Plate 3. Upper Neogene and Quaternary planktonic foraminifers. (All specimens with the exception of Figs. 1, 3, 10, and 11 are magnified $\times 82.5$.) 1-5. Globoquadrina dutertrei (d'Orbigny), (1) spiral view, $\times 73$, (2) side view, (3) umbilical view, $\times 73$. Sample 533-37-1, 47-49 cm. Lower Pleistocene, (4) umbilical view, (5) side view. Sample 533-2-2, 25-27 cm. Upper Pleistocene. 6-7. Globigerinella siphonifera (d' Orbigny), (6) apertural view. Sample 533-12,CC. Upper Pleistocene, (7) lateral view. Sample 533-2-2, 25-27 cm. Upper Pleistocene. 8-11. Globorotalia puncticulata (Deshayes), (8) umbilical view, (9) side view, (10) umbilical view, $\times 123.5$, (11) side view, $\times 123.5$. Sample 533A-29, CC. Middle Pliocene, Zone PL3. 

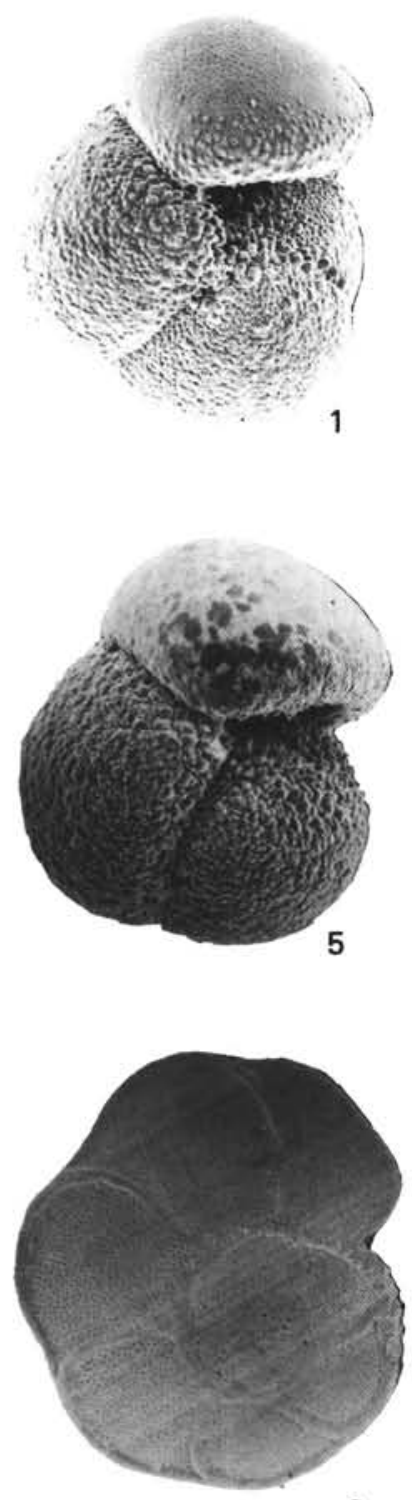

9

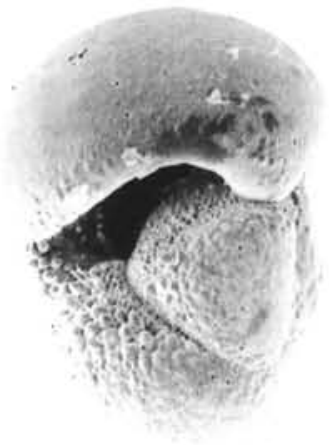

2
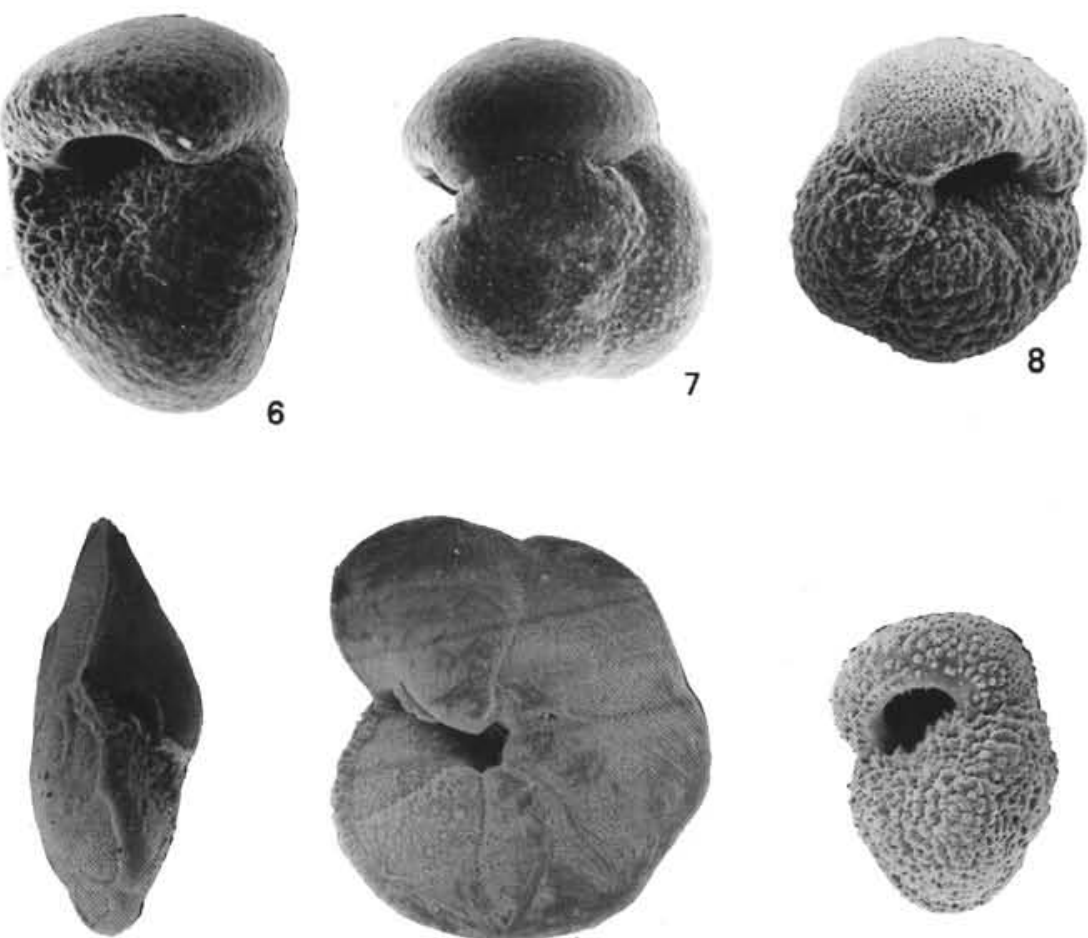

10
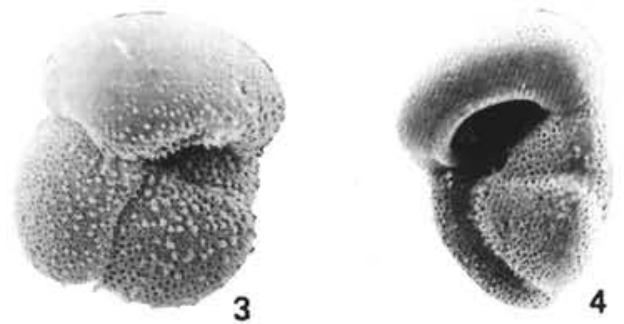

12

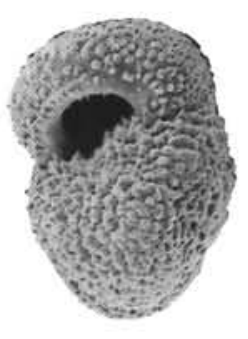

Plate 4. Upper Neogene and Quaternary planktonic foraminifers. (All specimens with the exception of Figs. 3, 4, and 10 are magnified $\times 82.5$ ). 1-7. Globorotalia inflata (d'Orbigny), (1) umbilical view, (2) side view, (3) umbilical view, $\times 90,(4)$ side view, $\times 90$. Sample $533-38 X, 17-19 \mathrm{~cm}$. Basal Pleistocene, (5) umbilical view, (6) side view, (7) spiral view. Sample 533-2-2, 25-27 cm. Upper Pleistocene. 8, 12. Globorotalia cf. inflata (d'Orbigny), (8) umbilical view, (12) side view. Sample 533-2-2, 25-27 cm. Upper Pleistocene. 9-11. Globorotalia praemiocenica Lamb and Beard, (9) spiral view, (10) side view, $\times 90$, (11) umbilical view. Sample 533A-29-3, 40-42 cm. Middle Pliocene, Zone PL3. 

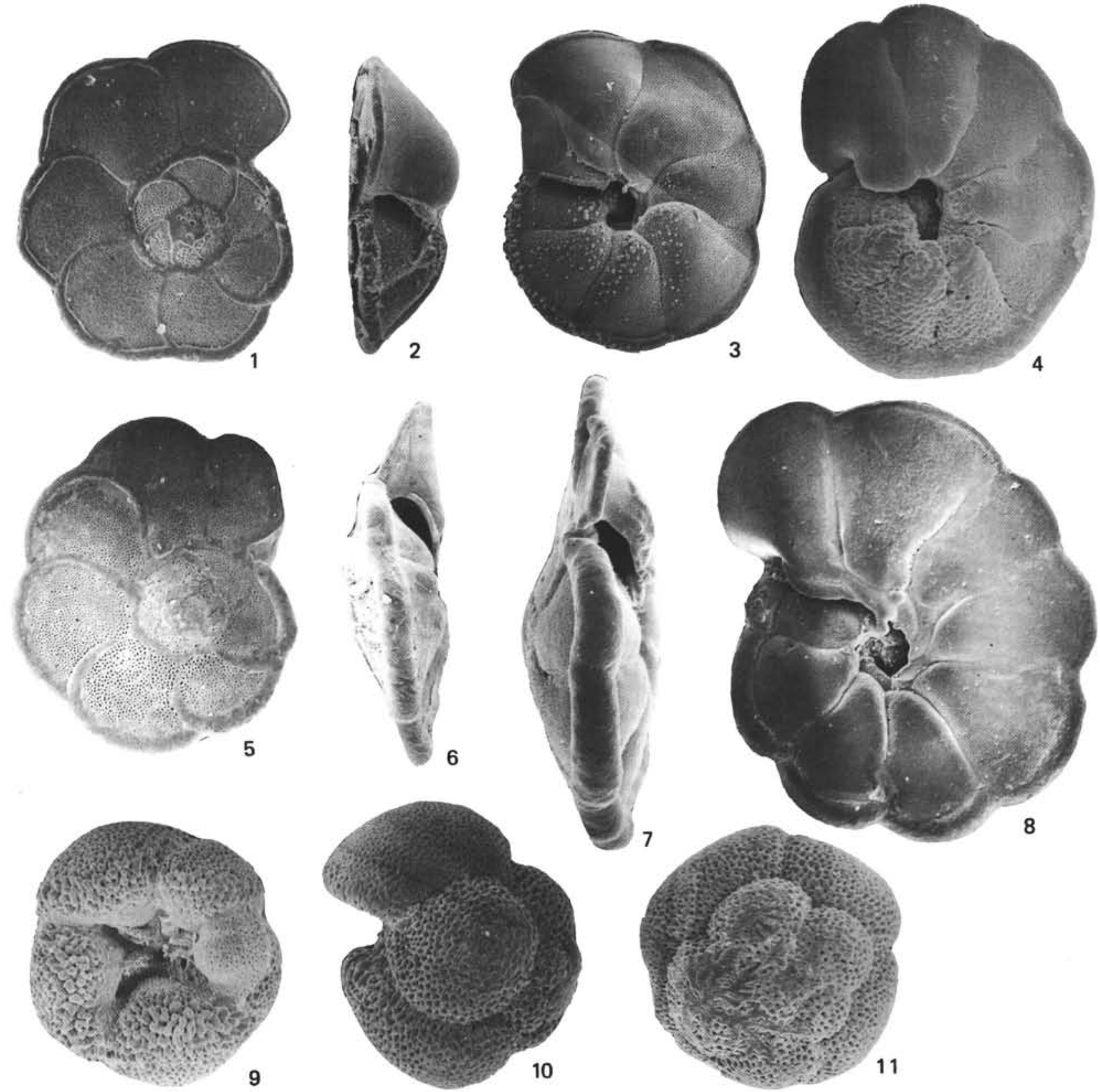

Plate 5. Upper Neogene and Quaternary planktonic foraminifers. (All specimens with the exception of Figs. 1, and 3-8 are magnified $\times 82.5$ ). 1-3. Globorotalia miocenica Palmer, (1) spiral view, $\times 78$, (2) side view, (3) umbilical view, $\times 78$. Sample 533A-3-4, 75-77 cm. Upper Pliocene, Zone PL5. 4. Globorotalia multicamerata Cushman and Jarvis, umbilical view, $\times 62$. Sample 533A-27,CC. Middle Pliocene, Zone PL3. 5-8. Globorotalia pertenuis Beard, (5) spiral view, $\times 62$, (6) side view, $\times 62$, (8) umbilical view, $\times 62$. Sample 533A-19,CC. Middle Pliocene, Zone PL3, (7) side view, $\times$ 73. Sample 533A-18,CC. Middle Pliocene, Zone PL3. 9-11. Globoquadrina altispira altispira (Cushman and Jarvis), (9) umbilical view, (10) side view, (11) spiral view. Sample 533A-29,CC. Middle Pliocene, Zone PL3. 

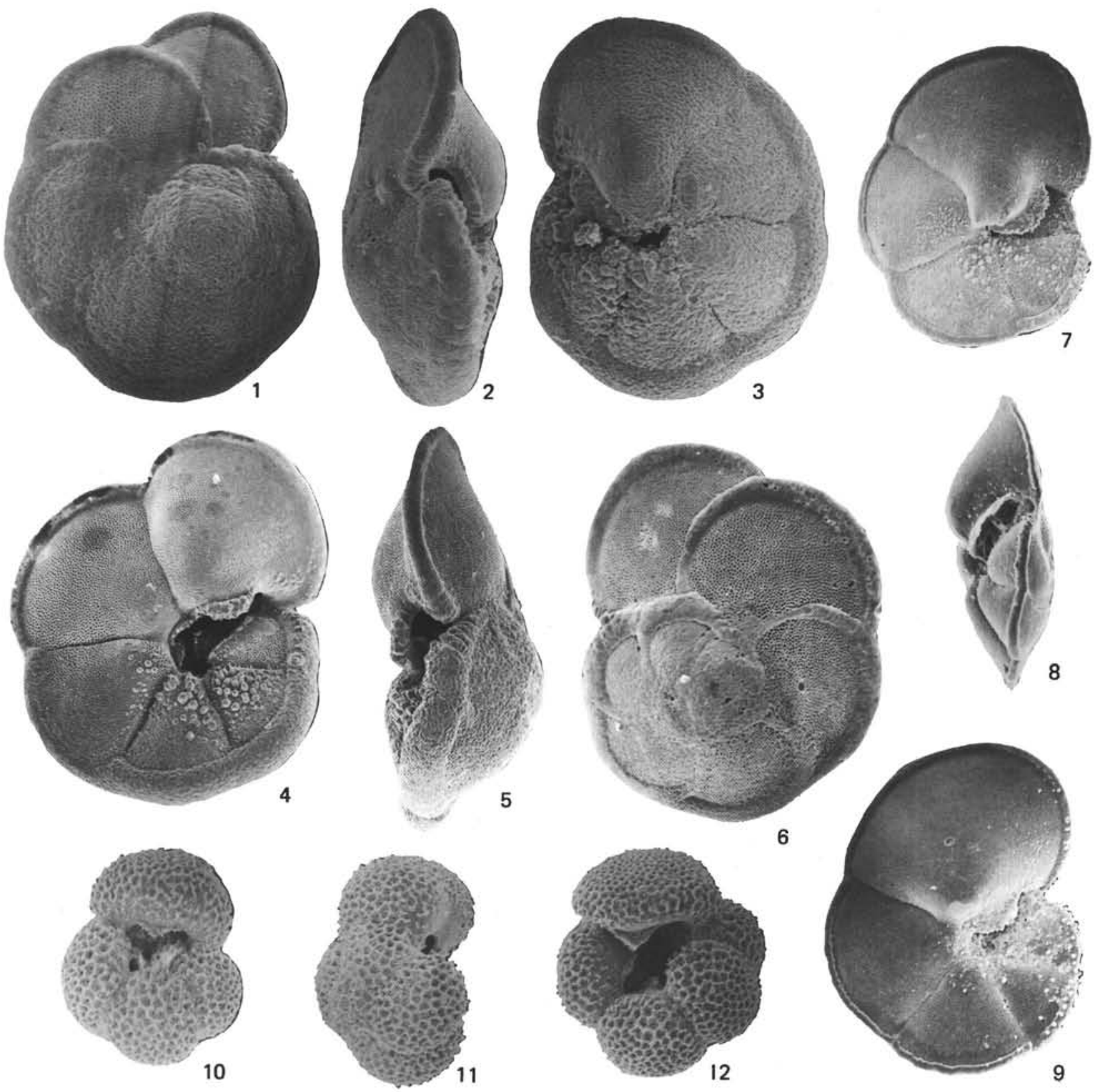

Plate 6. Upper Neogene and Quaternary planktonic foraminifers. (All specimens with the exception of Figs. 4-6, 8, and 10-12 are magnified $\times 82.5$ ). 1-3. Globorotalia $\mathrm{cf}$. tumida (Brady), (1) spiral view, (2) side view, (3) umbilical view. Sample 533A-22, CC. Middle Pliocene, Zone PL3. 4-6. Globorotalia tumida tumida (Brady), (4) umbilical view, $\times 55$, (6) spiral view, $\times 55$. Sample 533-26, CC. Lower Pleistocene, (5) side view, $\times 55$. Sample 533-25,CC. Lower Pleistocene. 7-9. Globorotalia gr. menardii-ungulata, (7) umbilical view. Sample 533-12,CC. Upper Pleistocene, (8) side view, $\times 110,(9)$ umbilical view. Sample 533-13,CC. Upper Pleistocene. 10-12. Globoquadrina altispira globosa Bolli, (10) umbilical view, $\times 100$, (11) side view, $\times 110$, (12) umbilical view, $\times 100$. Sample 533A-29-3, 40-42 cm. Middle Pliocene, Zone PL3. 

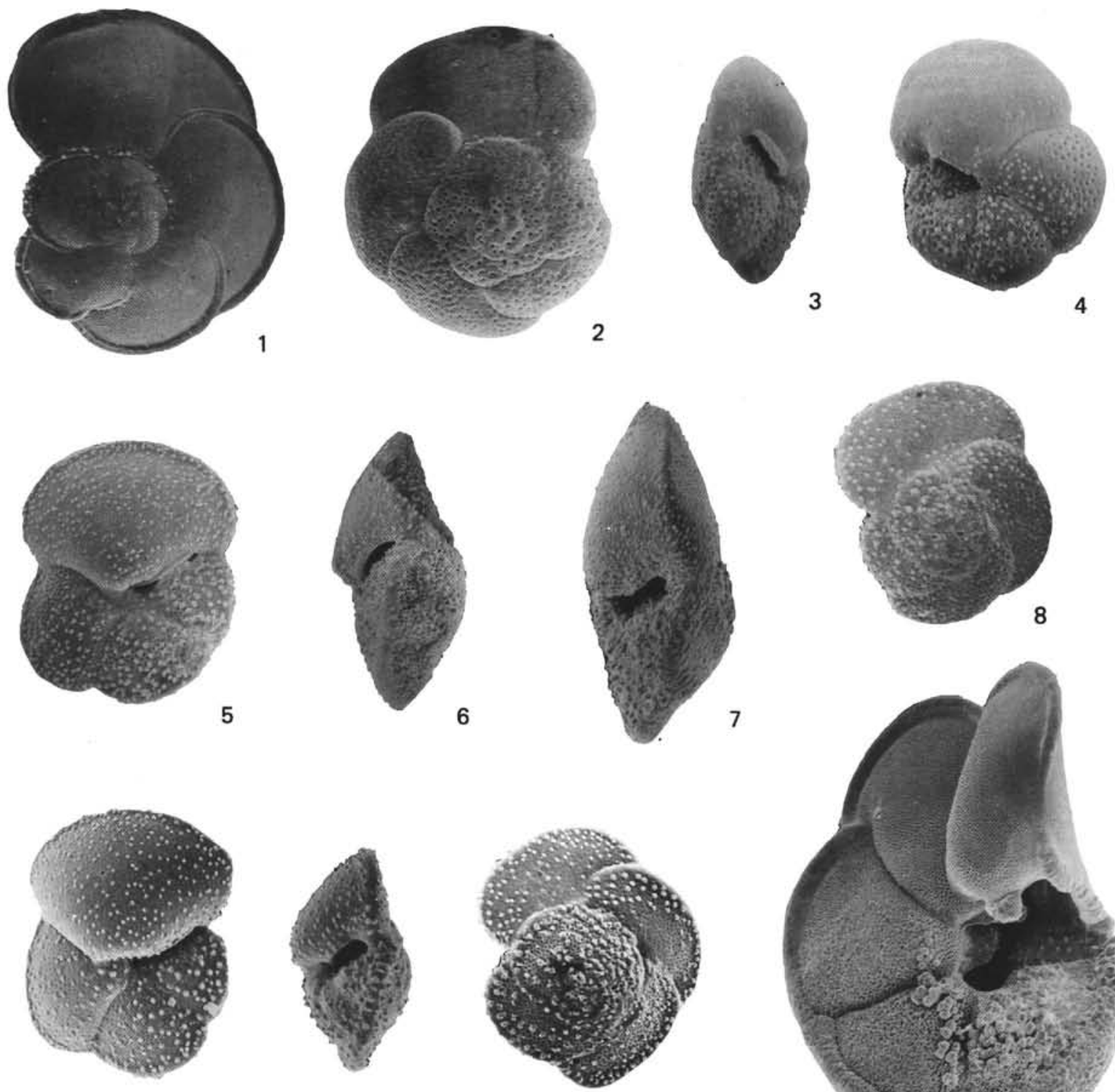

11

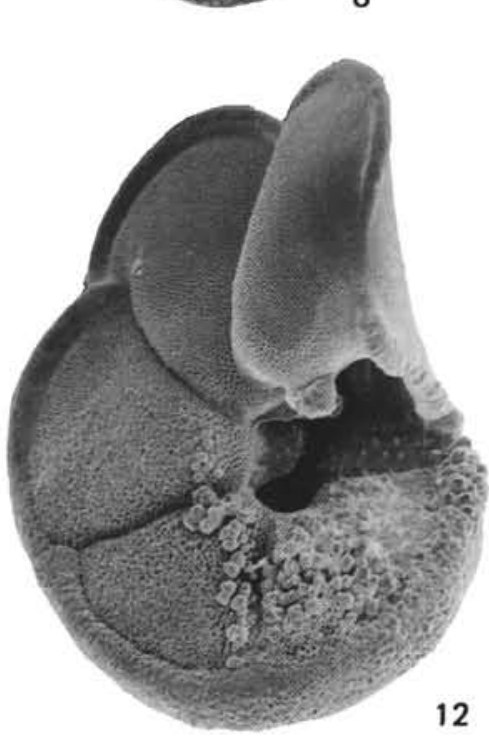

Plate 7. Upper Neogene and Quaternary planktonic foraminifers. 1. Globorotalia gr. menardii-ungulata, spiral view, $\times 87$. Sample 533-12,CC. Upper Pleistocene. 2-4. Globorotalia scitula (Brady), (2) spiral view, $\times 100$, (3) side view, $\times 100$, (4) umbilical view, $\times 100$. Sample 533 A24,CC. Middle Pliocene, Zone PL3. 5-8. Globorotalia praehirsuta Blow, (5) umbilical view, $\times 82.5,(8)$ spiral view, $\times 100$, Sample $533 \mathrm{~A}$ 24,CC. Middle Pliocene, Zone PL3, (6) side view, $\times 100$, (7) side view, $\times 82.5$. Sample 533A-27, CC. Middle Pliocene, Zone PL3. 9-11. Globorotalia aff. hirsuta (d'Orbigny) (umbilical side still more convex than spiral side), (9) umbilical view, $\times 90,(10)$ side view, $\times 90,(11)$ spiral view, $\times 90$. Sample 533-38X, 17-19 cm. Basal Pleistocene. 12. Globorotalia tumida flexuosa $($ Koch), umbilical view, $\times 55$. Sample 533-16,CC. Upper Pleistocene. 

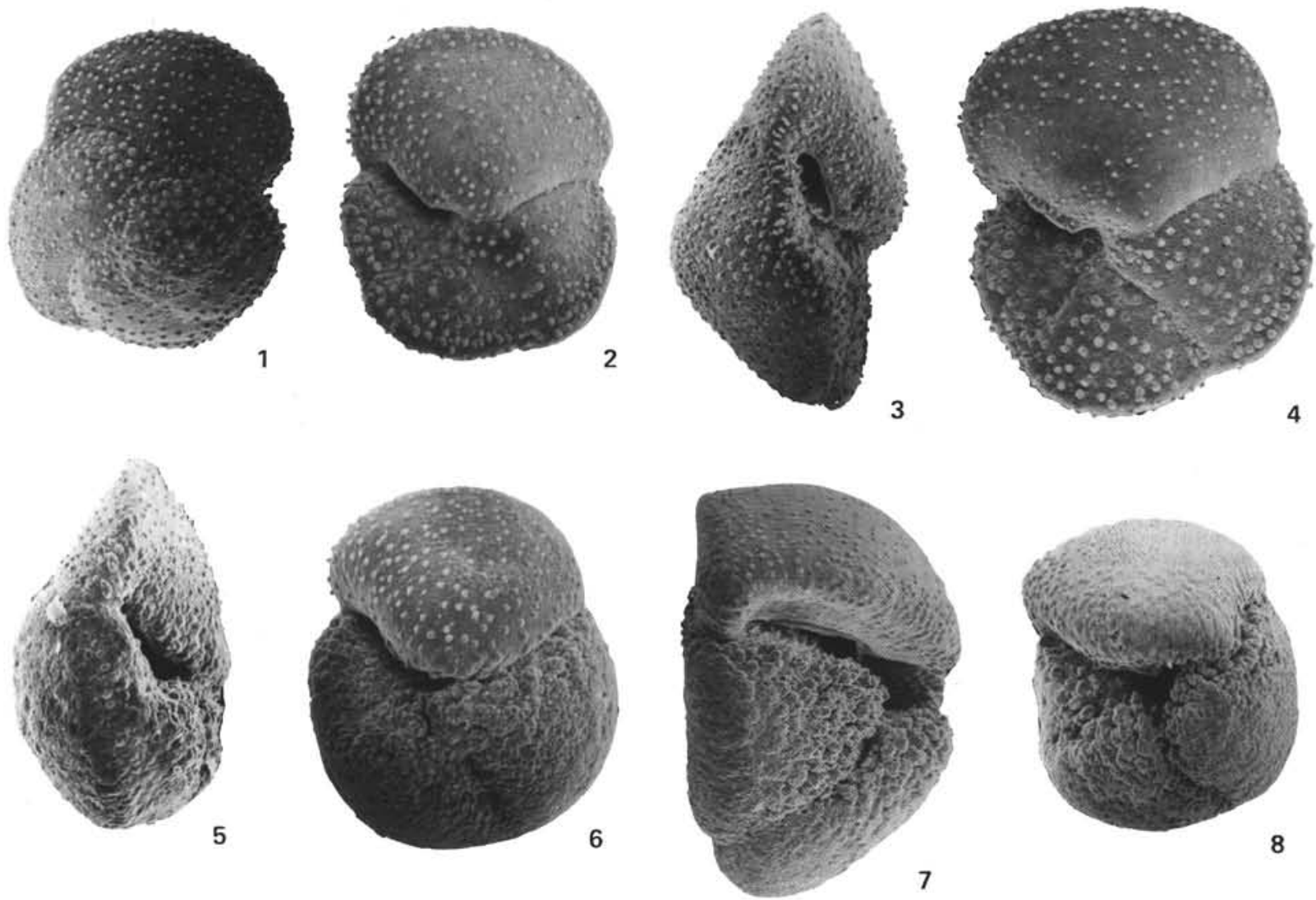

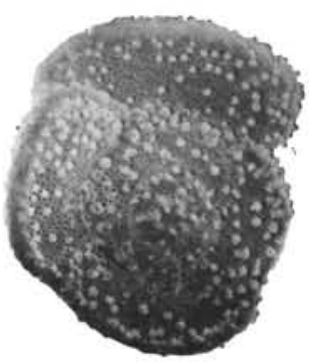

9

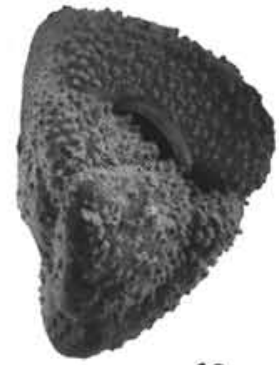

10

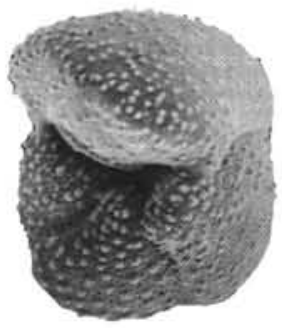

11

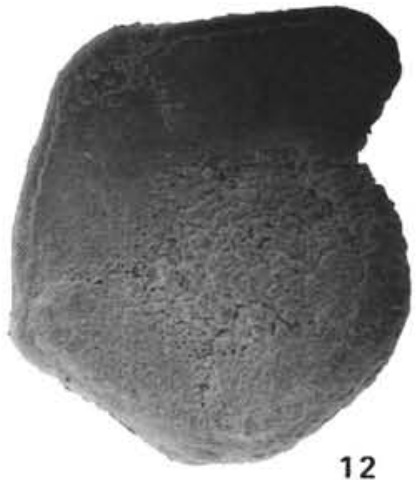

Plate 8. Upper Neogene and Quaternary planktonic foraminifers. 1-4. Globorotalia hirsuta (d'Orbigny), (1) spiral view, $\times 96$, (2) umbilical view, $\times 96$, (3) side view, $\times 96$, (4) umbilical view, $\times 96$. Sample 534-1-1, 9-11 cm. Holocene. 5-6. Globorotalia $\mathrm{cf}$. hirsuta (d'Orbigny) (incrusted form), (5) side view, $\times 82.5$. Sample 533-10,CC. Upper Pleistocene, (6) umbilical view, $\times 82.5$. Sample 533-11,CC. Upper Pleistocene. 7-11. Globorotalia gr. crassaformis (Galloway and Wissler), (7) side view, $\times 78,(8)$ umbilical view, $\times 78$, (9) spiral view, $\times 87$, (10) side view, $\times 82.5$, (11) umbilical view, $\times 87$. Sample 533-26,CC. Lower Pleistocene. 12. Globorotalia truncatulinoides (d'Orbigny), spiral view, $\times 73$. Sample 533-12,CC. Upper Pleistocene. 


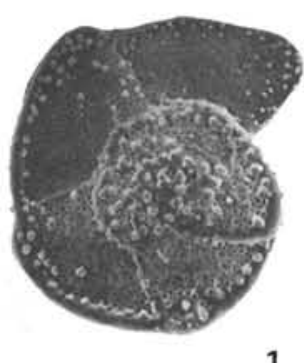

1

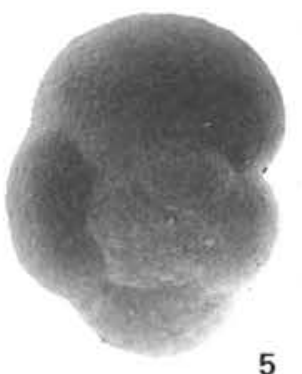

5

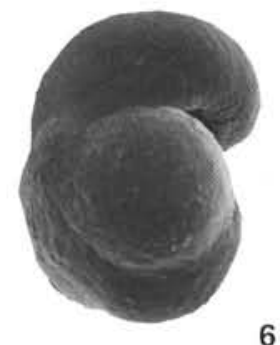

6

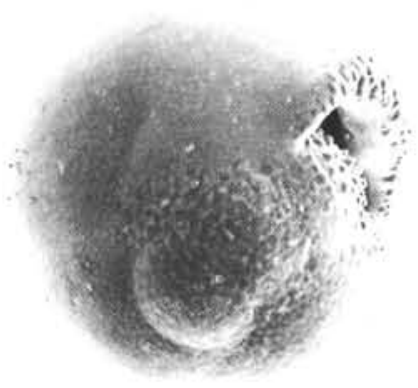

9

10
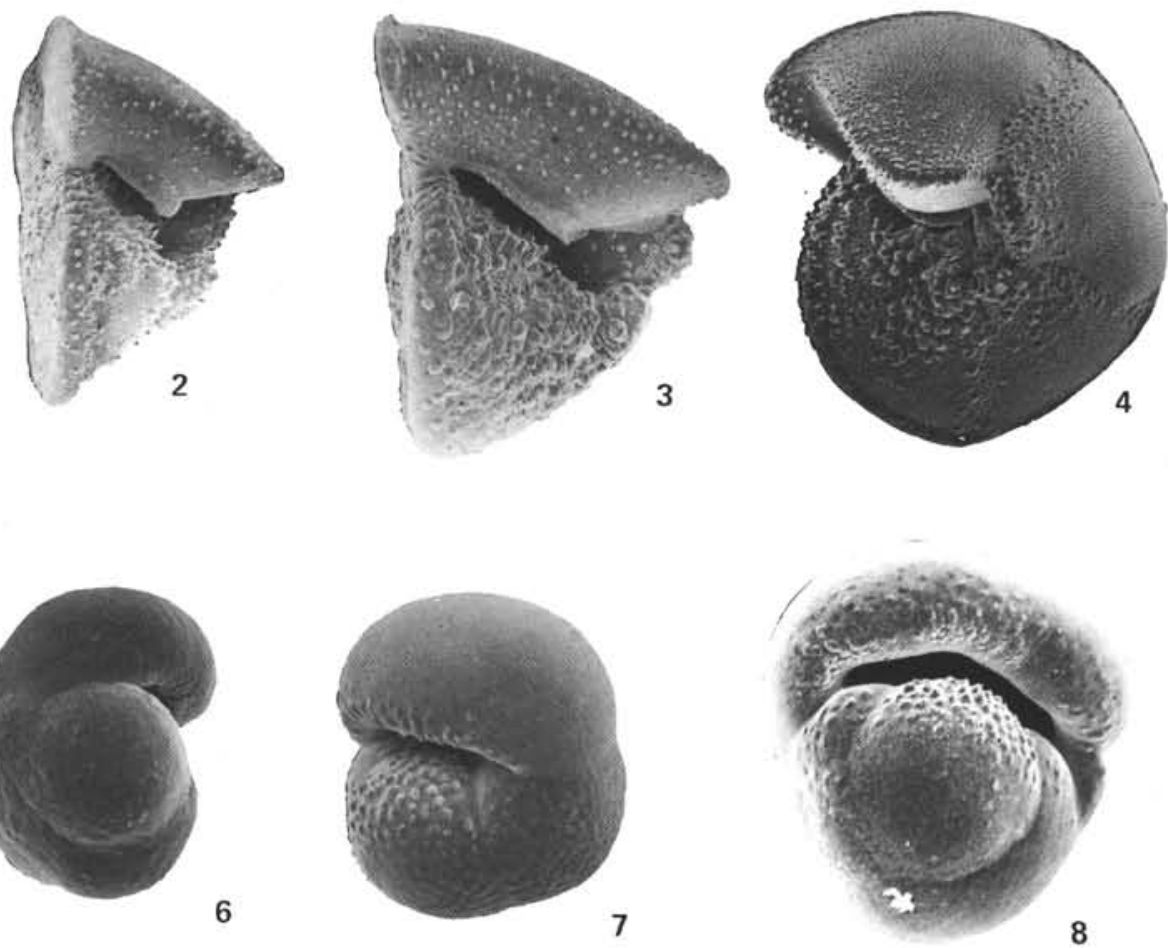

8

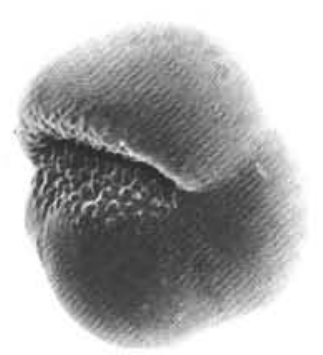

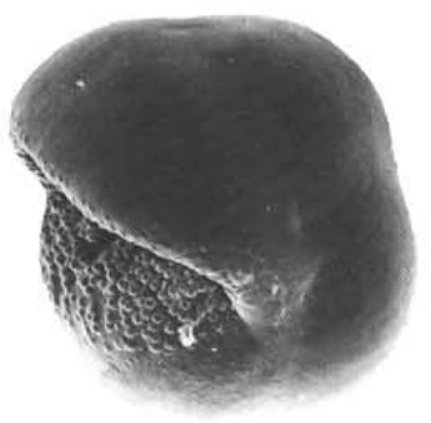

11

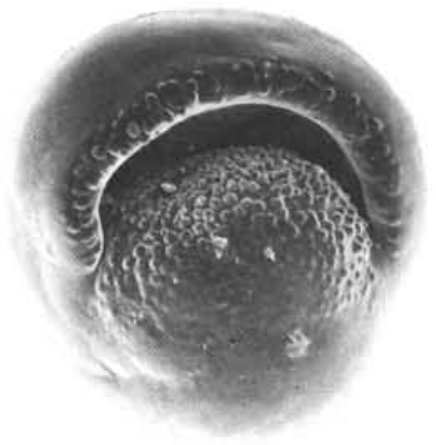

12

Plate 9. Upper Neogene and Quaternary planktonic foraminifers. (All specimens with the exception of Figs. 1, 8-9, and 11-12 are magnified $\times 82.5$ ). 1-4. Globorotalia truncatulinoides (d‘Orbigny), (1) spiral view, $\times 90$. Sample $533-12$,CC. Upper Pleistocene, (2) side view, (3) side view. Sample 533-26,CC. Lower Pleistocene, (4) umbilical view. Sample 533-25,CC. Lower Pleistocene. 5-7. Pulleniatina cf. okinawaensis Natori, (5) spiral view, (6) side view, (7) umbilical view. Sample 533-26,CC. Lower Pleistocene. 8-10. Pulleniatina obliquiloculata (Parker and Jones), (8) side view, $\times 87$, (9) spiral view, $\times 87,(10)$ umbilical view. Sample 533-25,CC. Lower Pleistocene. 11-12. Pulleniatina finalis Banner and Blow, (11) lateral view, $\times 73$, (12) apertural view, $\times 73$. Sample 533-15,CC. Upper Pleistocene. 


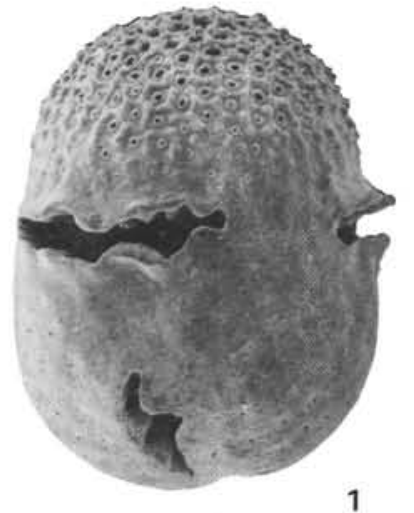

1

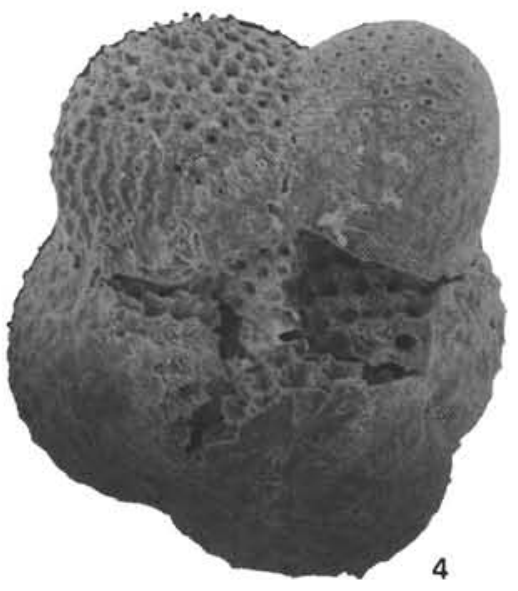

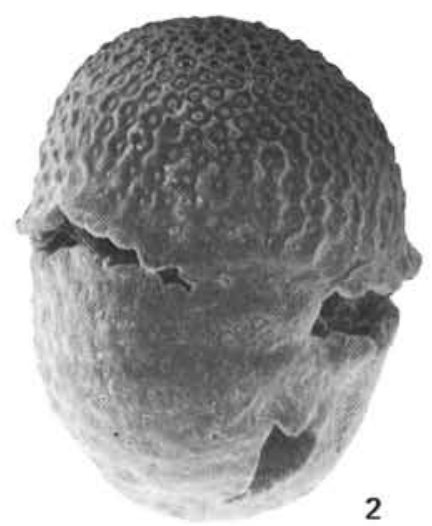

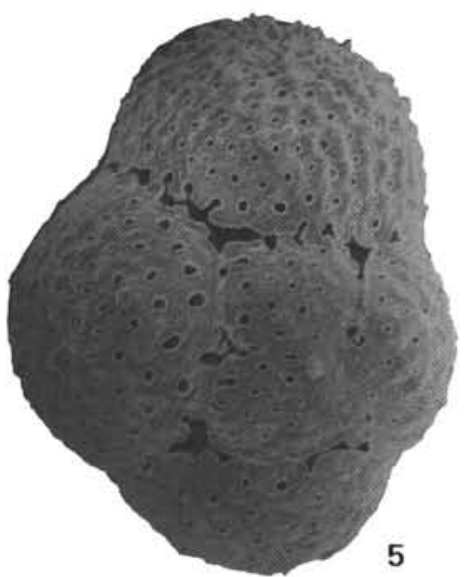

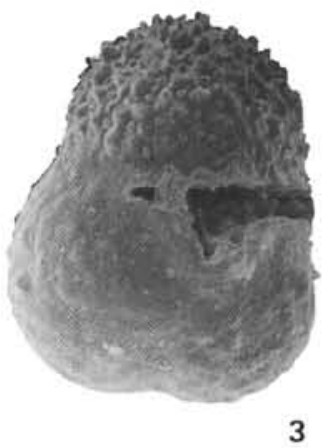

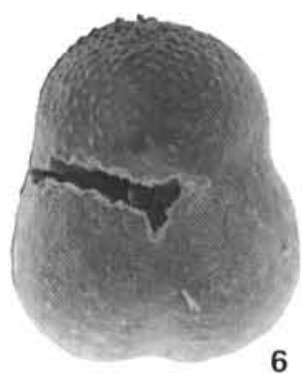

Plate 10. Upper Neogene and Quaternary planktonic foraminifers. (All specimens are magnified $\times 82.5$ ). 1-2. Sphaeroidinella dehiscens dehiscens (Parker and Jones). Sample 533-37-1, 47-49 cm. Basal Pleistocene. 3-6. Sphaeroidinellopsis gr. seminulina-subdehiscens, (3) umbilical view, (6) umbilical view. Sample 533A-27,CC. Middle Pliocene, Zone PL3, (4) umbilical view, (5) spiral view. Sample 533A-29,CC. Middle Pliocene, Zone PL3. 